\title{
Peer effects in college: how peers' performance can influence students' academic outcomes $^{1}$
}

\author{
Laetícia Rodrigues de Souza (Universidade Estadual de Campinas - UNICAMP) \\ Cristine Campos de Xavier Pinto (Fundação Getúlio Vargas - FGV-SP) \\ Bernardo Lanza Queiroz (Universidade Federal de Minas Gerais - UFMG) \\ Dimitri de Oliveira e Silva (Fundação Getúlio Vargas - FGV-SP)
}

\begin{abstract}
This paper investigates the existence of peer effects in academic outcomes by exploring specificities in the student's admission process of a Brazilian federal university, which works as a natural experiment. Individuals who are comparable in terms of previous academic achievement end up having classmates with better or worse performance in college because of the assignment rule of students to classrooms. Thus, our identification strategy for estimating peer effects on academic outcomes eliminates the endogenous selfselection into groups that would otherwise undermine the causal inference of peer effects. Overall, our findings showed that joining a class with high-ability students damages academic achievements of the lowestability students at UFMG. Although male and female students are both negatively affected by being in the first (better) class, we found gender differences. Specifically, being at the bottom of the better class make females take less radical decisions compared to male students in the sense that female students continue to study even though with lower performance (reduced GPA and credits earned) while male students seem to be more prone towards dropping out (increased number of subjects - or even University registration - cancelled and reduced attendance in classroom). We have also found other heterogeneities in peer effects in college in terms of class shift, period of admission, area of study and parents' education. This study is a necessary step before investigating the impact of peer quality on after-graduating decisions using the same natural experiment. This will allow us to deepen our understanding of how peer effects can also have long-lasting impacts.
\end{abstract}

\footnotetext{
${ }^{1}$ This study was supported by both The São Paulo Research Foundation (FAPESP - Project No: 2017/10.937-0) and the University of Campinas' Fund to Support Education, Research and Outreach (FAEPEX - Project No: 519.292 - 2753/17).
} 


\section{Introduction}

There is a large and growing literature on peer effects as researchers have long begun investigating the role of social interactions for explaining a series of individual behaviors. Peer influences may occur in different stages of the life cycle and in different environments. Some studies examine whether workers' productivity increases when they work alongside more productive coworkers (Cornelissen et al., 2017; Mas and Moretti, 2009). Other researchers are interested in investigating peer effects on health outcomes and risky behaviors of children, adolescents and youth, with examples ranging from the influence of peers on an individual's eating habits (Yakusheva et al., 2014; Trogdon et al., 2008; Fortin and Yazbeck, 2015) to the influence of peers on smoking, drinking, gambling, misbehavior, etc. (Eisenberg et al., 2014; Carrell and Hoekstra, 2010; Gaviria and Raphael, 2001; Elsner and Isphording, 2018).

Schools are very important environments for studying peer effects. Since kindergarten, most of individuals may spend half of their day in classrooms frequently interacting with more than a dozen other individuals. Moreover, a sizable portion of human capital accumulation takes place in schools and universities, which has consequences for individual productivity and wages. These are reasons why most studies about peer effects are based on information obtained from educational environments (e.g. Chetty et al., 2011; Trogdon et al., 2008; Carrell and Hoekstra, 2010; DeLay et al. 2016; Gaviria and Raphael, 2001; Eisenberg et al., 2014; Fortin and Yazbeck, 2015; Campos et al., 2015; Neidell and Waldfogel, 2010; Elsner and Isphording, 2018).

There is also strong evidence of peer effects on educational performance indicators and this is observed at every school level, from pre-kindergarten to college education. Neidell and Waldfogel (2010) verified robust effects of the quality of peers (based on students' test scores) in early education - kindergarten and early elementary grade - on math and reading outcomes among children in the United States. Analogously, De Melo (2014) provided evidence of positive effects of the performance of peers in reading and mathematics scores and mixed evidence on science in her study of Uruguayan primary schools. Using data from Florida elementary public schools, Burke and Sass (2013) found that students with low initial achievement levels appear to benefit less from an increase in the average ability of their peer group than do those with higher initial scores. Zimmerman (2003), Sacerdote (2001) and Carrel et al. (2009) found that roommates' background (such as High School class rank or grade point average - GPA) and current achievement (measured by college GPA) affect own achievement.

This paper fits into this literature. We investigate the existence of peer effects in college concerning different academic outcomes in a flagship university of Brazil. Peer effects on student performance may have important implications for designing college programs and courses. On one hand, if there are no peer effects, grouping students by levels of ability is desirable since teachers can adjust resources/classes according to each class' skills. On the other hand, if there are positive (negative) peer effects, (not) mixing poor-performing students with better ones may be more efficient as long as this does not harm the latter (Chen et al., 2015).

However, peer effects are notoriously difficult to estimate econometrically because in most contexts people choose with whom they associate. Therefore, while similarities in behavior among members within the same 
group may be due to peer effects, it is difficult to rule out the possibility that group members may be similar to each other along unobserved dimensions or may have come together with the intention of achieving similar outcomes (Kremer and Levy, 2008).

Using a unique dataset on students in one of the flagship universities in Brazil, we are able to deal with the identification challenges that plague the extant literature. We do so by exploring specificities in the Universidade Federal de Minas Gerais (UFMG) selection process. In particular, there is only one entrance exam per year, but based on this exam (called Vestibular), two classes of students are formed: one group begins the course in the first semester while the other begins in the second semester of each year. Roughly speaking, students who were admitted to the university are ranked according to their entrance exam score and the half portion with the best scores enter in the first semester, while the others enter in the second semester. This assignment rule causes some individuals who scored similarly in the entrance exam to have peers of very different quality in terms of previous achievement. Indeed, the worse ranked among those who entered in the first semester (also referred to as "first class" hereafter) usually have a similar score to the individuals best ranked among those who entered in the second semester (also "second class" hereafter), but the former have peers scoring better than the peers of the latter. Hence, by comparing academic outcomes of individuals who were at the margin of being assigned to different semesters we can estimate the extent of peer effects. Technically, the discontinuous assignment rule allows a causal inference of peer effects based on a regression discontinuity approach (Imbens and Lemieux, 2008; Lee and Lemieux, 2010, 2015).

In spite of the relevance of the subject, research exploring peer effects on student achievement in developing countries is extremely scarce (Asadullah and Chaudhury, 2008; Soetevent, 2006). In the case of Brazil, there are a few studies estimating the effects of peers in university environments (Poldin et al., 2015; André, 2016; Ribas et al., 2020; Motte and Oliveira, 2020) which reinforces the importance and contemporaneity of this research topic.

In order to deal with the endogeneity bias in peer group formation, Poldin et al. (2015) used an empirical approach based on 'predicted peers'. Based on the fact that individuals tend to interact with the ones more similar to them than otherwise, they assumed that peer groups are formed among students who have similar observable characteristics (region of origin and gender). Using data from two courses (Mechanical Engineering and Economics) at the Universidade Estadual de Campinas (UNICAMP), found that having high ability peers caused positive impact on academic performance. To this end, however, the authors run OLS models assuming that friendship among students is mainly determined by three attributes: same region of origin, same gender, or sharing the same study group. This implicitly considers that students with different characteristics do not become friends and therefore do not affect each other. This seems to be a strong assumption for ruling out the endogeneity in the estimation of peer effects.

The empirical approach used by André (2016), Ribas et al. (2020) and Motte and Oliveira (2020) is very similar to the one used in this paper. André (2016) also estimated peer effects on academic performance of undergraduate students enrolled in 2008 at an important university in Brazil (the Universidade Federal do Ceará) employing a similar natural experiment to ours in a regression discontinuity approach. Using the GPA 
as an indicator of academic performance, they found a negative effect (reduction of $2 \%$ in GPA) of being assigned to the first semester relative to being assigned to the second semester. Ribas et al. (2020) exploited the same assignment rule, but employed in a different Brazilian university (Universidade Federal de Pernambuco). They note that students assigned to the class with better peers also had worse academic outcomes. For that matter, they used several different performance indicators: first midterm grade, standardized course grade, GPA, failure by grade and by attendance, number of courses taken, missed first midterm and number of absences. Finally, Motte and Oliveira (2020) also exploited a discontinuity caused by a rule for the distribution of students between classes at another Brazilian university (Universidade Federal da Bahia) to estimate peers effects. They found that having the lowest performance among the best students of the class negatively affects ones' performance, especially for students from affirmative action programmes and for technology courses.

Although there are clear similarities between our research objectives and the studies mentioned in the previous paragraph, we offer another look at the phenomenon of peer effects in Brazilian universities. This paper goes deeper in estimating peer effects on college academic achievement by many different academic outcomes, such as grade point average (GPA), study situation at the end of the semester (whether cancelled or not), number of credits attempted, earned, cancelled or failed and sufficient attendance for passing. We also use a significantly longer period of analysis, between 1995 and 2013. Additionally, we estimate heterogeneity in peer effects in terms of gender, parent's education, period of admission, area of study or school shift. Finally, we have found results concerning differences in academic behaviors by gender that may be a novel in the current published studies about peer effects in college.

The question of whether classroom peer interactions matter for students learning has long been a concern for social scientists, educators, and policymakers. Why peer effects have attracted so much attention? Peer groups effects have had a prominent role in numerous policy debates (Hanushek et al., 2003). According to Soetevent (2006), this is so because, in general, policymakers aim at implementing a social policy that ultimately maximizes the welfare of the worst-off individuals. For achieving this goal it is necessary a thorough understanding of the determinants of the decision making process that takes place at the individual level. Neglecting social interaction effects that impact individual decisions is inefficient and may lead to undesirable outcomes and to a reconsideration of the costs and benefits of public policies and initiatives. Graham (2011) emphasizes that an effective policy-making requires knowledge of the causal mapping from group composition into outcomes. Any meaningful educational program would generate large changes in the allocation of students, and hence peer groups, across schools/universities. The magnitude and structure of any peer group effect in learning would be a key determinant of these changes. It would also determine their effects on the level and distribution of students' achievement. For these reasons knowledge of any peer spillover is required for optimal educational program design.

According to our findings, joining a class with high-ability students damages academic achievements of the lowest-ability students at UFMG. This general result is in line with what was found in empirical studies based on other Brazilian universities (Ribas et al. 2020; Motte and Oliveira, 2020). However, we found some results not yet reported in the literature in terms of gender differences in academic behaviors. Although male and 
female students are both negatively affected by being in the first (better) class, we found gender differences. Specifically, being at the bottom of the better class make females take less radical decisions compared to male students in the sense that female students continue to study even though with lower performance (reduced GPA and credits earned) while male students seem to be more prone towards dropping out (increased number of subjects - or even University registration - cancelled and reduced attendance in classroom). We have also found other heterogeneities in peer effects in college in terms of class shift, period of admission, area of study and parents' education. Studies like the one we propose here can help clarify some fundamental points to be considered when designing educational policies and, therefore, are of interest not only to university administrators, but also to parents, students, teachers and society as a whole.

This paper proceeds as follows. Section 2 describes the dataset, the sample restrictions, UFMG admission process and class assignment. Section 3 details our empirical strategy. Section 4 presents our findings, showing both the validation procedures for the RDD approach and the estimated peer effects. In Section 5 we summarize and discuss our empirical results and conclude the paper. Section 6 presents all figures and tables mentioned throughout the study.

\section{The dataset}

Studying the influence of peers on students' academic achievements has attracted considerable interest as it enhances our understanding of the educational process. However, measuring peer effects is a difficult task. This is so because students' outcomes depend on numerous factors and isolating peer influences is particularly problematic since people typically choose those with whom they associate (Zimmerman, 2003). We overcome these identification problems by exploiting class assignment at university in Brazil.

We use a rich set of administrative data from the Federal University of Minas Gerais (UFMG) covering the period of UFMG admissions between 1995 and 2013. Founded in 1927, UFMG is one of the best Brazilian higher education institutions. Based on indicators of research, innovation, internationalization, teaching and job market insertion, UFMG was classified as the fourth best university in the country (Ranking Universitário Folha 2019) and the seventh best university of America Latina (Times Higher Education (THE) World University Rankings 2019).

Being free of charge and holding a high quality status compared to their private counterparts, federal universities generally attract students from a wide range of socioeconomic backgrounds, and this makes the competition for a seat very fierce. In this context, UFMG is also one of Brazil's largest universities, with more than 3,100 professors and nearly 32,000 students enrolled in 90 undergraduate courses in 2015 (MEC and INEP, 2016).

It is imperative to highlight that although we had access to rich datasets on students' information (socioeconomic characteristics, Vestibular scores, grades in subjects, GPAs, attendance, etc) for the period 1995-2013, there are still some information missing. At this point, we do not have access to part of the data on Vestibular scores for year 2001 and to all data concerning the Vestibular scores for years 2002 to 2004 . Thus, 
our empirical analysis is based on an incomplete dataset for students admitted to UFMG in the period 19952013. However, we believe that the results reported here broadly reflect the results from a complete dataset.

\subsection{Sample restrictions}

The average number of students enrolled at UFMG per year rose continuously in the period, from less than 3,500 in 1995 to more than 6,500 in 2013 (among students admitted to UFMG by Vestibular in classroom programs/courses). For the whole period, the total number of students with information on Vestibular scores, performance indicators over their academic years and socioeconomic characteristics is 75,674 distributed in 73 programs. Our sample comprises 58,384 students admitted to UFMG through Vestibular in 44 courses with two different entrance classes/semesters (in the same shift). Thus, our sample corresponds to $77 \%$ of the total number of UFMG students and $60 \%$ of the total number of courses offered by the university in the period 1995-2013. There were 4 reasons for the exclusion of students from our final sample: 1 ) significantly different number of entrants in one of the classes of the program in a given admission year (usually programs with very small number of entrants in one of the classes), 2) the program did not offer two entrance classes in a given admission year, 3 ) the program offered two classes entrances but in different class shift in a given admission year, and 4) students who were excused from taking the subjects because they had already obtained these credits in another program or university. Table 1 details the number of students included in and excluded from our sample by program and class shifts².

\section{Table 1 about here}

\subsection{UFMG admission process and class assignment}

In Brazil, candidates need to choose their major in the application for a seat in a specific university (they are allowed to be admitted to only one per year) and if there is more than one class shift, they also choose which one they are applying for. The Vestibular has two rounds: the first evaluates students' general knowledge and only those who reach a minimum score go to the second phase. From 2010 onwards, the ENEM (National High School Exam) replaced the first round but the structure was kept the same as before.

UFMG began to organize its admission exams in the 1970s, and has always had a single selection process (called Vestibular) per year to fill two classes of students - the first class which begins in the first semester and the second class, beginning in the second. This decision was mainly related to logistics, due to the complexity involving the organization of this national admission exam. The only exceptions in this historical series are the years 2014 and 2015, in which there were two annual Vestibular editions. This is the reason why our period of analysis ends in 2013.

Students who were admitted to the university between 1995 and 2013 are ranked according to their entrance exam score and usually the half portion with the best scores enter in the first class, while the others enter in the second class. The final classification of candidates is published by the UFMG Admission Committee (Comissão Permanente do Vestibular - COPEVE) through its own website and local newspapers. According

\footnotetext{
${ }^{2}$ All mentioned tables and figures are presented at the end of this report (Section 6: Tables and Figures).
} 
to UFMG rules for admission, the programs that offer two entrance classes usually have virtually the same number of students and even though the second class starts 6 months later, all courses are offered every semester so that a student's curriculum is the same regardless of their class assignment. This way, although they are in different classes (that is, with different classmates), they are at the same institution, and in their first term students attend all courses together, not interacting academically with students other than the ones from their own class. As mentioned earlier, this assignment rule causes some individuals who scored similarly in the entrance exam to have peers of different quality in terms of previous achievement. Indeed, the worse ranked among those who entered in the first class have a similar score to the individuals best ranked among those who entered in the second class, but the former have peers scoring better than the peers of the latter.

In Figure 1, we show the relationship between students' final entrance score and class assignment. It is worth mentioning that: 1) the final entrance (Vestibular) score is standardized by program and entrance year using the first class cutoff and the standard deviation of admitted students' scores, and 2) class assignment is measured by a dummy variable assuming value 1 if enrollment is in the first class and 0 otherwise. The probability of enrollment is estimated using the triangular kernel function to construct the local-polynomial estimator and the bandwidth selection procedure first developed by Calonico et al. (2014).

Figure 1 shows that UFMG admission process creates a fuzzy discontinuity in the relationship between entrance score and enrollment in the first class. The probability of being assigned to the first class is $88.52 \%$ (Robust Std. Err.: 0.69\%) when considering all students and 89.02\% (Robust Std. Err.: 0.95\%) for female and $88.32 \%$ (Robust Std. Err.: $0.97 \%$ ) for male students. All 3 estimates are statistically significant at $1 \%$ level.

\section{Figure 1 about here}

\subsection{Descriptive Statistics}

Tables 2, 3 and 4 present descriptive statistics respectively for the harmonized variables in our dataset regarding socioeconomic characteristics ${ }^{3}$, for variables related to schooling before university admission and for characteristics related to the program and students' grade in their first term.

Table 2 shows that students initiate as undergraduates around age 20, with females being slightly younger than males (0.3 years). Most students live in Belo Horizonte (city where the main UFMG campus is located) and this percentage is higher for the students in the first class $(75 \%)$ compared to the ones in the second class $(70 \%)$. For the first class students, more than $46 \%$ of the mothers have completed college while less than $41 \%$ of the ones in the second class. Similar figures are found regarding fathers' education with these ones presenting a slightly higher percentage of college completion compared to mothers in both classes. Half the students in the first class declared more than 10 minimum wages as family income, in contrast to $43 \%$ of

\footnotetext{
${ }^{3}$ Since the dataset for the socioeconomic characteristics changed substantially overtime, some variables could not be harmonized, so that they were excluded from the analysis. Also, it is worth mentioning that the variable related to race/ skin color is not used in the analysis because it had more than $50 \%$ of missing information.
} 
their counterparts in the second class. Most students did not work: between $76 \%$ and $79 \%$ in both classes with a higher percentage for females ( $82 \%$ in the first class) than for males ( $75 \%$ in the first class).

\section{Table 2 about here}

Table 3 demonstrates that most of the students come from private or Federal public schools (with the latter being of superior quality in contrast to most of the State and Municipal public schools in Brazil). This percentage reaches more than $65 \%$ in the first class and almost $61 \%$ in the second class. For most students their High School classes were taken in day shift (more than $90 \%$ in both classes). Approximately $35 \%$ of students attended a preparatory course to university admission (Vestibular), with a higher percentage being males $(38 \%)$ than females $(32 \%)$.

\section{Table 3 about here}

Table 4 shows that $68 \%$ of students are enrolled in programs in the areas of Applied Sciences $(20 \%)$, Engineering $(20 \%)$ and Health $(28 \%)$ although, as is well known, the distribution over areas of study varies substantially by gender. For instance, while $32 \%$ of male students in the first class are enrolled in Engineering programs; this figure reaches only $9 \%$ for female students.

Besides all these covariates description carried out so far and as final considerations on the descriptive analysis of the UFMG students' data, Table 4 also presents the students' final entrance score ${ }^{4}$ (our assignment variable which allows us to estimate the peer effects) and students' performance indicators on their first term (our outcome variables of interest). As expected as a result of the UFMG process of class assignment (above described), the average final entrance score is higher in the first class compared to the second one. Additionally, most first term students' performance indicators suggest that the first classes indeed have "better students". This fact can be verified by the average GPA (which varies between 0 and 5 at UFMG), the average number of credits attempted, earned, cancelled and failed and the number of subjects with enough attendance. There is one additional performance indicator in Table 4 which is related to poor students' performance in their first term. This indicator is measured by the percentage of students with first term or University registration cancelled. It includes students who had credit points cancelados or trancados, which are two types of subjects cancellation often allowed in Brazilian universities.

\section{Table 4 about here}

Another feature that deserves attention in Table 4 is the comparison of academic results between male and female students. Although female students present a lower Vestibular score on average, their first term performance indicators show that they perform better than their male counterparts regarding all indicators: GPA, number of credits attempted, earned, cancelled, failed, percentage of students with first term or University registration cancelled and number of subjects with enough attendance in classroom. It is important

\footnotetext{
${ }^{4}$ As well as in Figure 1, Table 4 shows the standardized final entrance score (by program and admission year using the first class cutoff and the standard deviation of admitted students' scores).
} 
to highlight though that if the harder programs are chosen by female or male students their academic performance are not exactly comparable.

In summary, students in the first class showed to be more privileged than their counterparts in the second class regarding several characteristics, especially parents' education, place of residence, quality of high school, and family income. Thus, simply comparing both classes could be misleading given the differences in student's characteristics.

\section{Empirical strategy}

Rules for admission to UFMG establish that, before taking the entrance exam, each candidate can choose one program among the ones available at the university, according to their preferences. Then, based on the ranked preferences and scores of all candidates, each candidate is informed whether they were classified to enroll in their first choice of program, in their second choice, or whether they were not classified to enroll in any of them. This way, at the end of the process, all candidates are ranked by their scores in the entrance exam and this ranking determines the ones who were admitted to the university and those who were not (based on the number of seats available). Finally, university seats are filled according to the candidates' admission exam scores. Among the students admitted to a program, the ones with the best scores are given priority to entering in the first semester. However, they can choose to start classes in the second semester. If this is the case, the best student without this priority (the top one of the second half of the students) is then given the priority. This feature on the assignment of the admitted candidates - allocating students to first or second classes based on their scores - allows us to employ a Regression Discontinuity Design (RDD) approach to analyze peer effects among students in a Brazilian federal university environment.

The RDD offers a way of estimating treatment effects in a non-experimental setting where treatment is determined by whether an observed assignment variable exceeds a known cutoff point (Lee and Lemieux, 2010, 2015; Imbens and Lemieux, 2008). The main idea behind the RDD is that students with scores just above the cutoff (the ones assigned to enter in the first semester) are good comparisons to those just below the cutoff (who were allocated to the second semester). This way, the difference between the academic performance of both groups of students will be driven by the fact that the ones in the first class are surrounded by "better peers" in comparison to the ones assigned to the second class.

According to Fuzzy RDD approach, assignment to treatment is partially determined by the value of a predictor being on either side of a fixed threshold. Settings where treatment is only partially determined by whether the assignment variable crosses a cutoff point - as for example in cases of imperfect take-up by program participants or when factors other than the threshold rule affect the probability of program participation - are referred to as "fuzzy" RDD (Lee and Lemieux, 2015). Our analysis fits into this setting. Even with a higher probability of treatment (being allocated to the first class) when the assignment variable (the Vestibular score) crosses the threshold (the minimum score that fill the maximum number of students of the first class for a given program), this student can choose joining the second class, although the inverse is not true (the student not reaching the minimum score for the first class must join the second class). It is also possible that the 
students choose not to enroll because they chose another university, for example. However, these events are uncommon in the pool of applicants to UFMG selection process as we could see that the probability of being assigned to the first class is approximately $89 \%$ (Figure 1 ).

Let $y_{i}$ be a post-admission academic outcome of interest, $x_{j i}$ be the admission score of student $i$ in program $j$ and $x_{j}$ be the Vestibular score of the last student joining the first class. On one hand, if $x_{j i} \geq x_{j}$, the student may join either the first class $(c=1)$ or the second $(c=2)$ depending on their preference. On the other hand, if $x_{j i}<x_{j}$, the student has no choice besides going to the second class. This way, the expected difference in outcome $y_{i}$ between classes (specifically between the last student in the first class and the first one in the second class) is given by:

$$
\delta_{y}=E\left(y \mid c=1, x=x_{j}\right)-E\left(y \mid c=2, x=x_{j}\right)=\frac{\lim _{x \rightarrow x j} E\left(y \mid x \geq x_{j}\right)-\lim _{x \rightarrow x j} E\left(y \mid x<x_{j}\right)}{\lim _{x \rightarrow x j} \operatorname{Prob}\left(c=1 \mid x \geq x_{j}\right)}
$$

We are interested in examining different outcomes related to academic performance measures such as GPA, number of credits attempted, earned, cancelled or failed, percentage of students with first term or University registration cancelled and number of subjects with enough attendance. Peer effects on these outcomes were computed by running local linear regressions with triangular kernel weighting within small bandwidths around the Vestibular rank that determined whether students are assigned to one class or another (Lee and Lemieux, 2010). Optimal bandwidths were obtained according to Cattaneo et al. (2020).

\section{Results}

Before presenting the estimated peer effects on students' academic outcomes, we first show validation tests for the use of the RDD approach. Essentially, we examine: 1) whether the admission process was manipulated around the cutoff (the Vestibular score that assigns students to one class or the other) and 2) whether students assigned to the first class presented different characteristics from the ones of the second class. Finally, we show the effects of class assignment on students' academic performance.

\subsection{Validation of empirical strategy}

\subsubsection{Manipulation test}

As shown in Figure 1, students around the cutoff are almost $90 \%$ more likely to enroll in the first class. Our concern lies on the fact that if students declined being in the first or second class because they anticipated that they would be either in the worst class or they would be among the worse students, our sample would be biased. In order to rule out the possibility that the students deliberately behave this way, we show Figure 2 . It presents the density of enrolled students estimated for both sides of the cutoff separately along their respective confidence intervals. The overlap of the confidence intervals on both sides of the cutoff in this figure gives evidence that the density is continuous around the cutoff. This means that there is no evidence that the admission process is manipulated. 
We also applied the manipulation testing procedures (Table 5) based on the local polynomial density estimators proposed in Cattaneo et al. (2020), which is an updated version of the original McCrary's (2008) test. It formalizes the manipulation test shown in Figure 2 by testing the continuity of the density of the assignment variable (in our case, the Vestibular score) at the cutoff.

\section{Table 5 about here}

The lower panel of Table 5 shows the results from implementing the manipulation test. The final manipulation test statistic is equal to -0.6790 with a p-value of 0.4971 for the sample with all UFMG students. This finding indicates that even when the restricted model is used (meaning that there is a common bandwidth for selecting students at both sides of the cutoff: 0.335 for the sample with all students), we do not reject the null hypothesis of no manipulation. This is true for the three samples: all students, only females and only male students. Therefore, there is no statistical evidence of systematic manipulation of the running variable, which provides empirical evidence in favor of the validity of the RDD in this application.

\subsubsection{Balance of covariates}

Besides McCrary's test, we also examined whether students' characteristics were similar between the ones just below and the ones just above the Vestibular score cutoff that assigns them to the first or second classes. Our concern is that our findings may be determined by students' characteristics remaining unbalanced in the RDD. As previously shown, the UFMG dataset offers a rich set of information on students' characteristics. Table 6 shows the RDD estimates for all UFMG students' characteristics we could harmonize over the years. According to the estimates, students are very similar with regard to these observed characteristics. Regarding the sample with all students, among around 60 dummy variables, we only found a statistically significant difference between students in the first and second classes at $5 \%$ level in terms of having family income between 2 and 5 minimum wages (difference of $2.8 \%$ with p-value of $4.5 \%$ ) and in terms of having missing information on the number of family members (difference of $0.5 \%$ with p-value of $3.7 \%$ ). In the samples for female and male students, besides showing some statistically significant differences in family income and number of members, they also present some difference in terms of father's education, student's work status and program area. However, given the number of variables considered, it is completely conceivable that the null hypothesis can be rejected for one or another variable. This way, although the balance of our samples is not undermined, in order to improve the estimator's precision, we control all RDD estimates for all variables shown in Table 6.

Based on the fact that there is no evidence of manipulation and that the few students' characteristics unbalanced at the cutoff are taken into account in the estimates, there is a strong evidence for supporting the validity of our empirical exercise. As found by Ribas et al. (2020) when they applied this RDD with data on another flagship university in Brazil (UFPE), in general, the class assignment based on the Vestibular score ranking does not seem to affect the decision of students near the cutoff to enroll (or not) in the program they were admitted for. This students' behavior makes sense if we consider that UFMG is a high quality institution with no tuition fee. As a result, if on the one hand, losing the opportunity of studying in a high-quality institution 
represents a high opportunity cost, on the other hand, as we will show with our estimated peer effects (next section), students do not seem to anticipate the effects caused by being assigned to the first or second classes.

\section{Table 6 about here}

\subsection{Estimated peer effects}

\subsubsection{Gender heterogeneity in the effect of first-class enrollment on academic performance outcomes}

Roughly speaking, students in their first term only interact academically with their classmates. This feature begin to change in the following semesters as some students cancel enrollment or fail in some subjects, which brings other potential interactions that may bias the estimates of peer effects. For this reason, we are only analyzing first term academic performance indicators as outcomes in the empirical exercise.

Table 7 shows the effects of enrolling in the first class considering our three main samples: all UFMG students together (columns 1 trough 3), only female students (columns 4 trough 6 ) and only male students (columns 7 trough 9). For the matter of comparison, columns 1, 4 and 7 show the results for the reduced-form model columns 2, 5 and 8 show results for the Fuzzy RDD without controlling for any covariates and columns 3, 6 and 9 shows the results of the Fuzzy RDD taking into account the covariates described in Table 6 . The last 3 columns present our results of interest and these are the ones we are going to interpret henceforth, specifically the estimated effects highlighted in bold.

It is interesting to analyze the estimated effects presented in Table 7 jointly with Figures 3,4 and 5 . They present the fuzzy RDD estimates with covariates shown in Table 7 (in the vertical axis), calculated using a different bandwidths (in the horizontal axis). In these figures the main bandwidth (obtained with the procedure proposed by Cattaneo et al., 2020) is represented by a vertical line and robust confidence intervals are represented by the vertical bars.

Overall, Table 7 presents evidence that enrolling in the first class instead of the second seems to harm students' performance and this is true for both female and male students. The robustness of these results is confirmed by Figures 3,4 and 5, where the estimates are significant at $95 \%$ level under a wide range of bandwidths. Being on the first class reduces students GPA ( -0.16 points), the number of earned credits $(-0.69$ credits) and the number of subjects with enough attendance in classroom ( -0.15 subjects with enough attendance), at the same time that it increases the number of credits cancelled $(0.58$ credits) and the percentage of students with first term or University registration cancelled ( 0.026 percentage points).

\section{Table 7 about here}

Nevertheless, it is important to highlight some gender differences in the results reported in Table 7 as female students appear to be less negatively affected by being in the first class. It seems that being at the bottom of the better class make them take less radical decisions compared to male students' decisions. The relative 
disadvantage faced by first-class female students reduces their GPA and the number of credits earned, which seems to reflect a willingness or persistence to continue studying, despite the difficulties. On the other hand, the same relative disadvantage faced by male students in the first class increases their number of credits cancelled and the percentage of students with first term or university registration cancelled besides reducing the number of subjects with enough classroom attendance. The results for male students suggest that they seem to be more negatively influenced by being surrounded by better performing students in comparison to their female counterparts. Male students seem to be less persistent and more likely to make more definitive decisions early in their first term undergraduate program. While they give up attending classes, are more prone to cancel subjects or even cancel the first term or University registration, female students persist in the program, although obtaining lower GPA and credits during their first term.

Figures 3, 4 and 5 about here

4.2.2 Other heterogeneities in the effect of first-class enrollment on academic performance outcomes: school shift, period of University admission, areas of study and parents' education

Additionally, we estimated peer effects in university taking into account different heterogeneities: school shift (day or night), period of University admission (between 1995 and 2008 or between 2009 and 2013), areas of study (Agrarian, Biological and Physiological Sciences; Exact and Earth Sciences; Human Sciences; Applied Social Sciences; Engineering; Linguistics and Arts; and Health), and parents' education (both parents with College Degree, one of the parents with College Degree, neither parents with College Degree). We are going to briefly describe these extra results in the next paragraphs.

Table 8 presents the effects of being in the first class for students enrolled in programs whose classes are taken either in the day (columns 4 to 6 ) or the night shift (columns 7 to 9). Having better performing classmates seems to be especially deleterious to students' academic performance in programs whose classes are on the day shift. While it only reduces the GPA of students in the night shift, besides also having the GPA reduced, students in day-shift programs may also have their number of credits earned and the number of subjects with enough attendance in classroom (probably failing by attendance) reduced. Moreover, there is a higher percentage of students in programs taught during the day that may have their first term or university registration cancelled. One could speculate that as students in the night shift usually work during the day they are more focused in graduate (not feeling unmotivated by perceiving the existence of higherability classmates) or they are more collaborative with each other while those who study on the day shift are more competitive and less collaborative. However, these hypotheses cannot be investigated with the data available.

\section{Table 8 about here}

The results by period of admission at UFMG are shown in Table 9. We divided the students in two samples: the ones who were admitted to UFMG in period 1995-2008 and the ones who were admitted in 2009-2013. The idea was trying to examine whether the effects of having better performing classmates before affirmative 
actions were implemented in UFMG (they were first implemented in 2009 and were substantially expanded by 2012) were different from the effects for students admitted in a period without affirmative policies at the university. We found that being among the worst students in a class seems to damage student's performance in both periods, but it was more strongly negative in the period before the implementation of the affirmative actions at UFMG. In the period 1995-2008, students in the first class were more prone to have their first term or university registration cancelled and to have fewer subjects with enough attendance to pass than their counterparts in the subsequent years. Whether these policies made students more collaborative with each other or whether there are different mechanisms to explain these results is still an open question.

\section{Table 9 about here}

Table 10 reveals the impacts of being in the first class for students enrolled in programs of different areas of study. Overall, the results suggest there are no significant peer effects for students in the following areas: Agrarian, Biological and Physiological Sciences, Exact and Earth Sciences, Human Sciences, and Applied Social Sciences. Students in the three remaining areas experience negative effects of having better performing classmates. Engineering is the area in which students seems to be more negatively affected by being among the worst students in the class as they are more likely to stop attending classes and among Engineering programs there is a higher percentage of students whose first semester or their university registration has been cancelled. As done by Ribas et al. (2020), it would be important to verify whether these different behaviors (depending on the area of study) are attributable to either the share of females in the classes, the competitiveness of admission or the curriculum's level of difficulty. We are waiting for the complete dataset to continue doing these and other analyzes.

\section{Table 10 about here}

As one would expect, not only the characteristics of the program chosen by students, but also their family characteristics can influence the effects of being among the worst academic performers of the class. Table 11 shows the effects of having better performing peers in classroom over three samples of students: the ones whose both parents have college degree, the ones whose only one of them has college and the ones whose neither parents have college degree. This table tells a very consistent story regarding the heterogeneity by parents' education of peers effects in the university context: students with either only one of the parents or neither one having college are more likely to be negatively affected by having better performing peers in classroom. Specifically, students whose both parents have college tend to increase their number of credits earned for being in the first class, while students with at least one of parents not having college are more prone to experience a decrease in GPA, the number of credits earned and the number of subjects with enough attendance, besides being more prone to have credits cancelled and to present a higher percentage of students with first term or university registration cancelled.

Table 11 about here

\section{Discussion and Conclusion}


The recent and growing literature on peer effects is not conclusive about the existence or direction of peer effects on students' academic performance in any educational level (Oosterbeek and Ewijk, 2014; Park et al., 2018; Neidell and Waldfogel, 2010; Burke and Sass, 2013; Sacerdote, 2011; Marotta, 2017). This study contributes to previous work mainly by: 1) taking into account different academic outcomes, such as GPA, study situation at the end of the semester (whether cancelled or not), number of credits attempted, earned, cancelled, failed and whether there was sufficient attendance to pass; 2) the use of a significantly long period of analysis, between 1995 and 2013 and; 3) identifying whether there are heterogeneities in peer effects in terms of gender, parent's education, period of admission, area of study or school shift. Moreover, this study brings new evidence on peer effects in a developing country which is still scarce in the literature.

According to common sense, one could assume that being part of a better group of individuals would be the best option. This is not always true when it comes to college education. Overall, our findings show that joining a class with high-ability students can damage academic achievements of the lower-ability students at UFMG. These findings are in line with the other studies that used data from other Brazilian public universities, in particular, Ribas et al. (2020), Motte and Oliveira (2020) and André (2016). UFMG is a flagship Brazilian university and our sample comprised more than 58,000 students admitted to the university between years 1995 and 2013. We found that both male and female students are negatively affected by being in the first (better) class. However, there are gender differences in academic behavior that deserve to be highlighted. We found that being at the bottom of the better class make females take less radical decisions in comparison to male students. The relative disadvantage faced by first-class female students reduces their GPA and the number of credits earned, which seems to reflect a willingness or persistence to continue studying, despite the difficulties. On the other hand, the same relative disadvantage faced by male students in the first class increases their number of credits cancelled and the percentage of students with first term or university registration cancelled besides reducing the number of subjects with enough attendance to pass.

We have also investigated other potential heterogeneities in peer effects at the university level and we found that: 1) Having better performing classmates seems to be especially deleterious to students' academic performance in programs whose classes are in day shift in comparison to night shift; 2) Considering two periods of admission to UFMG, one before the implementation of affirmative action policies (1995-2008) and the other after this implementation (2009-2013), we found that being among the worst students in a class seemed to damage student's performance in both periods, but that was more strongly negative in the period before the implementation of the affirmative actions at UFMG; 3 ) Dividing the students according to the study area of the programs, Engineering, Health and Linguistic and Arts students experience negative effects of being in the first class, and this effect is stronger for students of Engineering programs; and 4) students with either only one of the parents or neither one having college are more likely to be negatively affected by having better performing peers in classroom compared to the ones whose both parents have college degree.

However, it is important to think about the limitations of our empirical investigation. We were only able to examine peer effects for the students with the lowest performance in a university class, which means that we cannot extrapolate our findings for the remaining students in the class (the average ones, for instance). Some researchers have found, for example, that students with higher initial scores seem to benefit more from having 
high-ability classmates than less able students (Androushchak et al., 2013; Burke and Sass, 2013). Another limitation is the fact that the reason why there are negative effects of being in the first class could be due to both peer quality per se and the ranking effect. The negative feeling of being at the bottom of the class can outweigh the benefit of having high-ability classmates (Carrell et al., 2013; Ribas et al., 2020). Based on data for students of another flagship university in Brazil (UFPE), Ribas et al. (2020) found that these negative effects seem to be dominated by the ranking effect. The authors also mention that this fact may help explain the dissenting findings in the literature. However, we were not able to disentangle our estimated peer effects in order to verify whether our results are mainly due to either the ranking effect or peers quality. Finally, due to the non-availability of data so far, we did not control for teacher fixed effects. It is possible though that most UFMG students selected to both the first and the second classes are taught by the same teachers so that our estimates may already be taking it into account. Moreover, as argued by Ribas et al. (2020), although there are differences in peer quality between the first and second classes, no university program can discriminate students by offering different courses or professors. This way, potential differences in teachers may be negligible. In this context, some researchers have already found no evidence that instructors adjust their teaching to the composition of the classes (Booij et al., 2017).

The fact that students with different levels of academic achievement may have their performance impaired or improved depending on the performance of their classmates matters for the design of educational policies. If low-performing students benefit less from high-ability classmates than better performing students, in order to maximize overall achievement, it would be recommended a more homogenous classroom. However, if this is only true for the very-low-achievers (but not for the remaining students), overall achievement would be maximized with a more diverse environment in classroom. Whether this is the case, tracking the low-ability students would be important to improve their interactions with other students (Booij et al., 2017). A reasonable educational policy may be able to lessen students' difficulties on interacting with different students. University administration can facilitate communication among students, manipulate dormmates assignment and track students' progress aiming at diversifying student's contacts and subsequently improve their academic performance (Poldin et al., 2015; Booij et al., 2017). 


\section{Tables and Figures}

\subsection{Tables}

TABLE 1: Number of Students Included in (and Excluded from) our Sample by areas of study, program and class shift - UFMG students with University admission between 1995-2013

\begin{tabular}{|c|c|c|c|c|c|c|c|}
\hline \multirow[b]{2}{*}{ Area of study } & \multicolumn{3}{|c|}{ Included in our sample } & \multirow[b]{2}{*}{ Area of study } & \multicolumn{3}{|c|}{ Not included in our sample } \\
\hline & Program & $\begin{array}{l}\text { Class } \\
\text { shift }\end{array}$ & $\begin{array}{l}\text { Number of } \\
\text { students }\end{array}$ & & Program & $\begin{array}{l}\text { Class } \\
\text { shift }\end{array}$ & $\begin{array}{l}\text { Number of } \\
\text { students }\end{array}$ \\
\hline \multirow{5}{*}{$\begin{array}{l}\text { Agricultural, } \\
\text { Biological and } \\
\text { Physiological } \\
\text { Sciences }\end{array}$} & Aquaculture & Day & 219 & \multirow{3}{*}{$\begin{array}{l}\text { Agricultural, } \\
\text { Biological and } \\
\text { Physiological } \\
\text { Sciences }\end{array}$} & Agronomy & Day & 413 \\
\hline & Biological Sciences & Day & 1,354 & & Animal Science & Day & 307 \\
\hline & Biological Sciences & Night & 1,085 & & $\underline{\text { Total }}$ & - & 720 \\
\hline & Veterinary Medicine & Day & 1,786 & \multirow{15}{*}{$\begin{array}{l}\text { Exact and Earth } \\
\text { Sciences }\end{array}$} & Actuarial Science & Day & 222 \\
\hline & Total & - & 4,444 & & Statistics & Day & 552 \\
\hline \multirow{5}{*}{$\begin{array}{l}\text { Exact and } \\
\text { Earth } \\
\text { Sciences }\end{array}$} & Computer Science & Day & 1,170 & & Physics & Day & 248 \\
\hline & Physics & Day & 502 & & Physics & Night & 611 \\
\hline & Math & Day & 497 & & Geography & Day & 623 \\
\hline & Information Systems & Day & 317 & & Geography & Night & 760 \\
\hline & Total & - & 2,486 & & Geology & Day & 511 \\
\hline \multirow{5}{*}{$\begin{array}{l}\text { Human } \\
\text { Sciences }\end{array}$} & Social Sciences & Day & 1,208 & & Mathematics & Day & 389 \\
\hline & $\begin{array}{l}\text { Social } \\
\text { Communication }\end{array}$ & Day & 1,065 & & Mathematics & Night & 593 \\
\hline & Public Management & Night & 393 & & $\begin{array}{l}\text { Computational } \\
\text { Mathematics }\end{array}$ & Day & 216 \\
\hline & Psychology & Day & 1,929 & & Chemistry & Day & 642 \\
\hline & Total & - & 4,595 & & Chemistry & Night & 565 \\
\hline \multirow{10}{*}{$\begin{array}{l}\text { Applied Social } \\
\text { Sciences }\end{array}$} & $\begin{array}{l}\text { Architecture and } \\
\text { Urbanism }\end{array}$ & Day & 1,391 & & $\begin{array}{l}\text { Technological } \\
\text { Chemistry }\end{array}$ & Night & 155 \\
\hline & $\begin{array}{l}\text { Architecture and } \\
\text { Urbanism }\end{array}$ & Night & 295 & & $\begin{array}{l}\text { Information } \\
\text { Systems }\end{array}$ & Day & 197 \\
\hline & Library Science & Day & 1,214 & & Total & - & 6,284 \\
\hline & Accounting & Night & 1,265 & \multirow{11}{*}{ Human Sciences } & Anthropology & Night & 155 \\
\hline & Government Studies & Day & 1,264 & & $\begin{array}{l}\text { Environmental } \\
\text { Social Science }\end{array}$ & Night & 199 \\
\hline & Economics & Day & 4,014 & & $\begin{array}{l}\text { Social } \\
\text { Communication }\end{array}$ & Day & 257 \\
\hline & Law & Day & 1,791 & & $\begin{array}{l}\text { Social } \\
\text { Communication }\end{array}$ & Night & 154 \\
\hline & Law & Night & 532 & & Philosophy & Day & 672 \\
\hline & $\begin{array}{l}\text { Tourism } \\
\text { Management }\end{array}$ & Day & & & Philosophy & Night & 149 \\
\hline & Total & - & 11,766 & & History & Day & 678 \\
\hline \multirow{4}{*}{ Engineering } & $\begin{array}{l}\text { Aerospace } \\
\text { Engineering }\end{array}$ & Day & 245 & & History & Night & 675 \\
\hline & $\begin{array}{l}\text { Environmental } \\
\text { Engineering }\end{array}$ & Day & 249 & & Pedagogy & Day & 952 \\
\hline & Civil Engineering & Day & 3,154 & & Pedagogy & Night & 954 \\
\hline & $\begin{array}{l}\text { Mechatronic } \\
\text { Engineering }\end{array}$ & Day & 941 & & $\underline{\text { Total }}$ & - & 4,845 \\
\hline
\end{tabular}


TABLE 1: Number of Students Included in (and Excluded from) our Sample by areas of study, program and class shift - UFMG students with University admission between 1995-2013

(end)

\begin{tabular}{|c|c|c|c|c|c|c|c|}
\hline \multirow[b]{2}{*}{ Area of study } & \multicolumn{3}{|c|}{ Included in our sample } & \multirow[b]{2}{*}{ Area of study } & \multicolumn{3}{|c|}{ Not included in our sample } \\
\hline & $\begin{array}{c}\text { Undergraduate } \\
\text { course }\end{array}$ & $\begin{array}{l}\text { Class } \\
\text { shift }\end{array}$ & $\begin{array}{l}\text { Number of } \\
\text { students }\end{array}$ & & $\begin{array}{c}\text { Undergraduate } \\
\text { course }\end{array}$ & $\begin{array}{l}\text { Class } \\
\text { shift }\end{array}$ & $\begin{array}{l}\text { Number of } \\
\text { students }\end{array}$ \\
\hline \multirow{11}{*}{ Engineering } & $\begin{array}{l}\text { Mechatronic } \\
\text { Engineering }\end{array}$ & Night & 278 & \multirow{10}{*}{$\begin{array}{l}\text { Applied Social } \\
\text { Sciences }\end{array}$} & Business & Day & 775 \\
\hline & Mining engineering & Day & 794 & & Business & Night & 786 \\
\hline & $\begin{array}{l}\text { Production } \\
\text { engineering }\end{array}$ & Day & 826 & & $\begin{array}{l}\text { Business (campus } \\
\text { Montes Claros) }\end{array}$ & Night & 190 \\
\hline & $\begin{array}{l}\text { Computer Systems } \\
\text { Engineering }\end{array}$ & Night & 195 & & Archival science & Night & 192 \\
\hline & $\begin{array}{l}\text { Electrical } \\
\text { Engineering }\end{array}$ & Day & 1,528 & & Library Science & Night & 477 \\
\hline & $\begin{array}{l}\text { Mechanical } \\
\text { Engineering }\end{array}$ & Day & 1,328 & & $\begin{array}{l}\text { Government } \\
\text { Studies }\end{array}$ & Day & 240 \\
\hline & $\begin{array}{l}\text { Mechanical } \\
\text { Engineering }\end{array}$ & Night & 793 & & $\begin{array}{l}\text { Finance and } \\
\text { Controllership }\end{array}$ & Day & 195 \\
\hline & $\begin{array}{l}\text { Engineering with } \\
\text { Metallurgy }\end{array}$ & Day & 836 & & Museology & Day & 153 \\
\hline & $\begin{array}{l}\text { Chemical } \\
\text { Engineering }\end{array}$ & Day & 849 & & $\begin{array}{l}\text { International } \\
\text { Relations }\end{array}$ & Night & 192 \\
\hline & Total & - & 12,016 & & Total & - & 3,200 \\
\hline & Visual Arts & Day & 1,079 & & $\begin{array}{l}\text { Agricultural and } \\
\text { Environmental } \\
\text { Engineering }\end{array}$ & Day & 194 \\
\hline \multirow{12}{*}{$\begin{array}{l}\text { Linguistics } \\
\text { and Arts }\end{array}$} & Design & Night & 290 & Engineering & Food Engineering & Night & 187 \\
\hline & Modern Languages & Day & 2,587 & & Forest Engineering & Day & 198 \\
\hline & Modern Languages & Night & 2,482 & & Total & - & 579 \\
\hline & Theatre & Day & 390 & \multirow{8}{*}{$\begin{array}{l}\text { Linguistics and } \\
\text { Arts }\end{array}$} & Cinematography & Night & 197 \\
\hline & $\underline{\text { Total }}$ & - & 6,828 & & $\begin{array}{l}\text { Conservation and } \\
\text { Restoration }\end{array}$ & Day & 179 \\
\hline & Biomedicine & Night & 159 & & Dance & Night & 79 \\
\hline & Physical Education & Day & 1,742 & & Fashion Design & Night & 222 \\
\hline & Nursing & Day & 1,490 & & Musicology & Day & 631 \\
\hline & Pharmacology & Day & 2,074 & & Musicology & Night & 276 \\
\hline & Pharmacology & Night & 313 & & Theatre & Day & 20 \\
\hline & Physiotherapy & Day & 869 & & Total & - & 1,604 \\
\hline & Speech Therapy & Day & 495 & \multirow[b]{2}{*}{ Health } & Physical Education & Night & 58 \\
\hline \multirow[t]{7}{*}{ Health } & $\begin{array}{l}\text { Health Service } \\
\text { Management }\end{array}$ & Night & 439 & & $\underline{\text { Total }}$ & - & 58 \\
\hline & Medicine & Day & 5,037 & & & & \\
\hline & Nutrition & Day & 598 & & & & \\
\hline & Dentistry & Day & 1,918 & & & & \\
\hline & $\begin{array}{l}\text { Radiology } \\
\text { Technology }\end{array}$ & Night & 293 & & & & \\
\hline & $\begin{array}{l}\text { Occupational } \\
\text { therapy }\end{array}$ & Day & 822 & & & & \\
\hline & $\underline{\text { Total }}$ & - & 16,249 & & & & \\
\hline \multicolumn{2}{|c|}{ Total Number of Included Students } & & 58,384 & \multicolumn{2}{|c|}{ Total Number of Not-Included Students } & & 17,290 \\
\hline
\end{tabular}

Source: Academic Registration and Control Department - Universidade Federal de Minas Gerais (DRCA - UFMG). 
TABLE 2: Socioeconomic characteristics - UFMG students with University admission between 1995-2013

(to be continued)

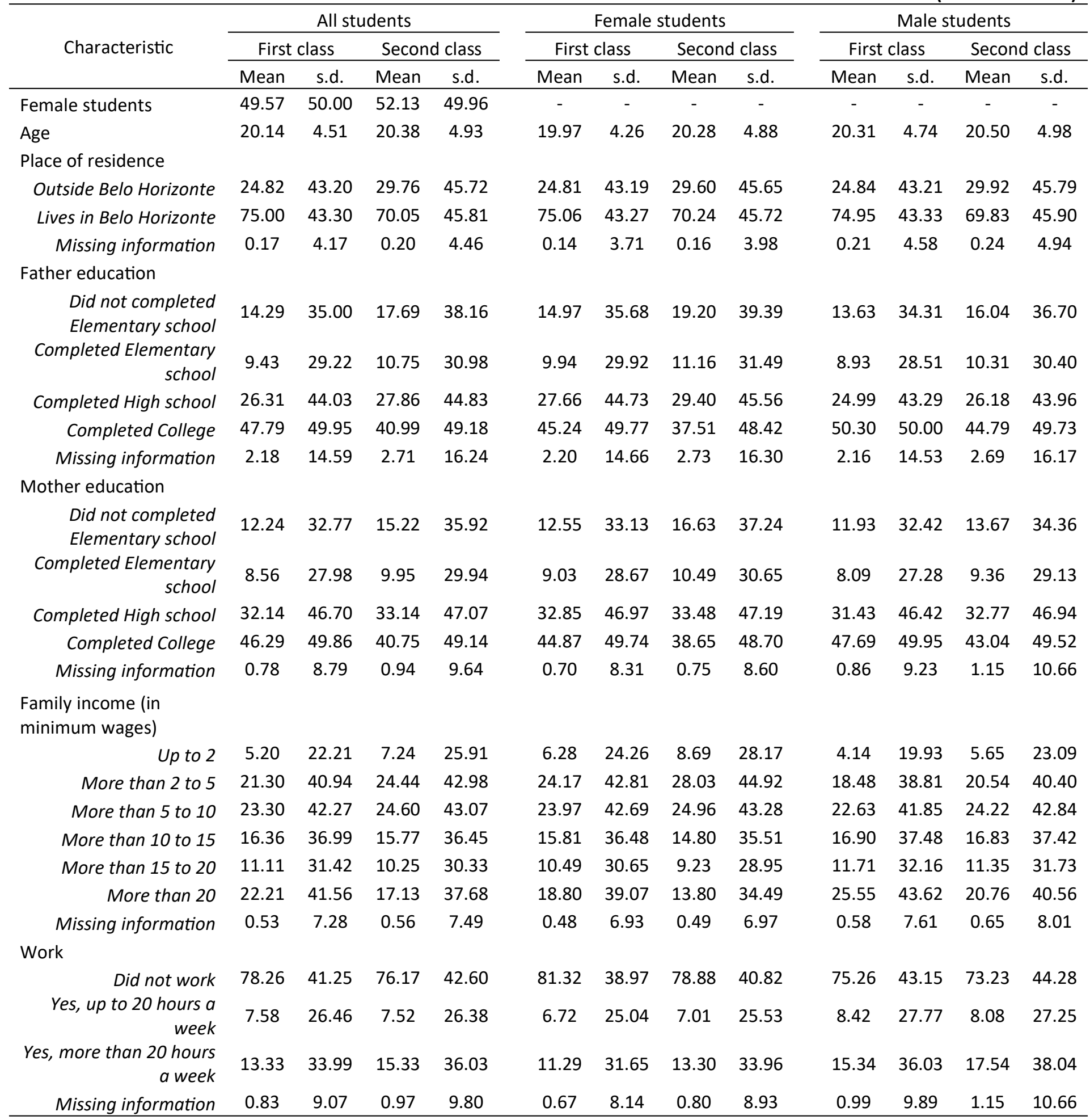


TABLE 2: Socioeconomic characteristics - UFMG students with University admission between 1995-2013

(end)

\begin{tabular}{|c|c|c|c|c|c|c|c|c|c|c|c|c|}
\hline \multirow{3}{*}{ Characteristic } & \multicolumn{4}{|c|}{ All students } & \multicolumn{4}{|c|}{ Female students } & \multicolumn{4}{|c|}{ Male students } \\
\hline & \multicolumn{2}{|c|}{ First class } & \multicolumn{2}{|c|}{ Second class } & \multicolumn{2}{|c|}{ First class } & \multicolumn{2}{|c|}{ Second class } & \multicolumn{2}{|c|}{ First class } & \multicolumn{2}{|c|}{ Second class } \\
\hline & Mean & s.d. & Mean & s.d. & Mean & s.d. & Mean & s.d. & Mean & s.d. & Mean & s.d. \\
\hline \multicolumn{13}{|l|}{$\begin{array}{l}\text { Contribution to family } \\
\text { income }\end{array}$} \\
\hline $\begin{array}{r}\text { Did not work, did not } \\
\text { contributed }\end{array}$ & 78.52 & 41.07 & 76.16 & 42.61 & 81.64 & 38.72 & 78.95 & 40.76 & 75.46 & 43.03 & 73.12 & 44.34 \\
\hline $\begin{array}{r}\text { Worked, contributed } \\
\text { partially }\end{array}$ & 12.50 & 33.07 & 14.41 & 35.12 & 11.40 & 31.78 & 13.47 & 34.14 & 13.58 & 34.26 & 15.44 & 36.13 \\
\hline $\begin{array}{r}\text { Worked, main } \\
\text { responsible }\end{array}$ & 2.64 & 16.04 & 2.91 & 16.80 & 1.57 & 12.43 & 1.95 & 13.84 & 3.70 & 18.86 & 3.95 & 19.48 \\
\hline 2 or 3 & 25.08 & 43.35 & 25.71 & 43.71 & 25.01 & 43.31 & 25.07 & 43.34 & 25.16 & 43.39 & 26.41 & 44.09 \\
\hline 4 or 5 & 61.82 & 48.58 & 60.17 & 48.96 & 62.87 & 48.32 & 61.01 & 48.77 & 60.79 & 48.82 & 59.25 & 49.14 \\
\hline 6 or more & 10.59 & 30.77 & 11.41 & 31.80 & 10.42 & 30.56 & 11.69 & 32.14 & 10.75 & 30.97 & 11.11 & 31.43 \\
\hline Missing information & 0.31 & 5.59 & 0.35 & 5.88 & 0.25 & 5.04 & 0.30 & 5.50 & 0.37 & 6.09 & 0.39 & 6.27 \\
\hline Number of students & \multicolumn{2}{|c|}{29,301} & \multicolumn{2}{|c|}{29,087} & \multicolumn{2}{|c|}{14,525} & \multicolumn{2}{|c|}{15,162} & \multicolumn{2}{|c|}{14,776} & \multicolumn{2}{|c|}{13,925} \\
\hline
\end{tabular}

Source: Academic Registration and Control Department - Universidade Federal de Minas Gerais (DRCA - UFMG). 
TABLE 3: Characteristics related to schooling before the University admission - UFMG students with University admission between 1995-2013

\begin{tabular}{|c|c|c|c|c|c|c|c|c|c|c|c|c|}
\hline \multirow{3}{*}{ Characteristic } & \multicolumn{4}{|c|}{ All students } & \multicolumn{4}{|c|}{ Female students } & \multicolumn{4}{|c|}{ Male students } \\
\hline & \multicolumn{2}{|c|}{ First class } & \multicolumn{2}{|c|}{ Second class } & \multicolumn{2}{|c|}{ First class } & \multicolumn{2}{|c|}{ Second class } & \multicolumn{2}{|c|}{ First class } & \multicolumn{2}{|c|}{ Second class } \\
\hline & Mean & s.d. & Mean & s.d. & Mean & s.d. & Mean & s.d. & Mean & s.d. & Mean & s.d. \\
\hline \multicolumn{13}{|l|}{ Type of school } \\
\hline Private & 53.20 & 49.90 & 51.07 & 49.99 & 53.43 & 49.88 & 51.09 & 49.99 & 52.96 & 49.91 & 51.04 & 49.99 \\
\hline $\begin{array}{r}\text { Federal public } \\
\text { school }\end{array}$ & 11.94 & 32.42 & 9.61 & 29.47 & 9.60 & 29.46 & 6.99 & 25.50 & 14.24 & 34.95 & 12.46 & 33.03 \\
\hline $\begin{array}{r}\text { State/Municipal } \\
\text { public school }\end{array}$ & 34.57 & 47.56 & 38.97 & 48.77 & 36.76 & 48.22 & 41.66 & 49.30 & 32.42 & 46.81 & 36.04 & 48.01 \\
\hline $\begin{array}{r}\text { Missing } \\
\text { information }\end{array}$ & 0.30 & 5.44 & 0.35 & 5.94 & 0.21 & 4.62 & 0.26 & 5.07 & 0.38 & 6.14 & 0.46 & 6.76 \\
\hline \multicolumn{13}{|l|}{$\begin{array}{l}\text { School shift in } \\
\text { High School }\end{array}$} \\
\hline Night & 6.19 & 24.11 & 9.17 & 28.86 & 5.10 & 22.00 & 8.05 & 27.20 & 7.27 & 25.96 & 10.39 & 30.52 \\
\hline Day & 93.54 & 24.58 & 90.61 & 29.16 & 94.70 & 22.41 & 91.78 & 27.46 & 92.41 & 26.49 & 89.34 & 30.86 \\
\hline $\begin{array}{r}\text { Missing } \\
\text { information }\end{array}$ & 0.26 & 5.12 & 0.22 & 4.65 & 0.20 & 4.46 & 0.17 & 4.14 & 0.32 & 5.69 & 0.27 & 5.15 \\
\hline \multicolumn{13}{|l|}{$\begin{array}{l}\text { College } \\
\text { preparatory } \\
\text { course }\end{array}$} \\
\hline Yes & 35.15 & 47.75 & 34.86 & 47.65 & 32.20 & 46.73 & 33.23 & 47.10 & 38.05 & 48.55 & 36.63 & 48.18 \\
\hline No & 64.67 & 47.80 & 64.96 & 47.71 & 67.66 & 46.78 & 66.65 & 47.15 & 61.73 & 48.61 & 63.12 & 48.25 \\
\hline $\begin{array}{r}\text { Missing } \\
\text { information }\end{array}$ & 0.18 & 4.25 & 0.18 & 4.22 & 0.14 & 3.80 & 0.12 & 3.44 & 0.22 & 4.65 & 0.24 & 4.94 \\
\hline \multicolumn{13}{|l|}{$\begin{array}{l}\text { Previous } \\
\text { entrance exams }\end{array}$} \\
\hline No & 24.34 & 42.91 & 25.82 & 43.77 & 23.69 & 42.52 & 25.55 & 43.62 & 24.98 & 43.29 & 26.12 & 43.93 \\
\hline \multicolumn{13}{|l|}{ Yes, has College } \\
\hline $\begin{array}{r}\text { diploma or is } \\
\text { enrolled in } \\
\text { College }\end{array}$ & 15.67 & 36.35 & 13.47 & 34.14 & 14.13 & 34.84 & 12.07 & 32.58 & 17.18 & 37.72 & 14.99 & 35.70 \\
\hline $\begin{array}{r}\text { Yes, other } \\
\text { situation }\end{array}$ & 59.82 & 49.03 & 60.55 & 48.88 & 62.02 & 48.53 & 62.26 & 48.47 & 57.65 & 49.41 & 58.69 & 49.24 \\
\hline $\begin{array}{r}\text { Missing } \\
\text { information }\end{array}$ & 0.17 & 4.09 & 0.16 & 4.02 & 0.15 & 3.89 & 0.12 & 3.44 & 0.18 & 4.27 & 0.21 & 4.56 \\
\hline $\begin{array}{l}\text { Number of } \\
\text { students }\end{array}$ & & 29,301 & & 29,087 & & 14,525 & & 15,162 & & 14,776 & & 13,925 \\
\hline
\end{tabular}

Source: Academic Registration and Control Department - Universidade Federal de Minas Gerais (DRCA - UFMG). 
TABLE 4: Characteristics related to the program and students' grades in the first term - UFMG students with University admission between 1995-2013

\begin{tabular}{|c|c|c|c|c|c|c|c|c|c|c|c|c|}
\hline \multirow{3}{*}{ Characteristic } & \multicolumn{4}{|c|}{ All students } & \multicolumn{4}{|c|}{ Female students } & \multicolumn{4}{|c|}{ Male students } \\
\hline & \multicolumn{2}{|c|}{ First class } & \multicolumn{2}{|c|}{ Second class } & \multicolumn{2}{|c|}{ First class } & \multicolumn{2}{|c|}{ Second class } & \multicolumn{2}{|c|}{ First class } & \multicolumn{2}{|c|}{ Second class } \\
\hline & Mean & s.d. & Mean & s.d. & Mean & s.d. & Mean & s.d. & Mean & s.d. & Mean & s.d. \\
\hline \multicolumn{13}{|l|}{ Related to the } \\
\hline \multicolumn{13}{|l|}{ Program } \\
\hline \multicolumn{13}{|l|}{ Area of study } \\
\hline \multicolumn{13}{|l|}{ Agrarian, Biological } \\
\hline $\begin{array}{r}\text { and Physiological } \\
\text { Sciences }\end{array}$ & 7.56 & 26.44 & 7.66 & 26.6 & 8.87 & 28.43 & 8.7 & 28.18 & 6.28 & 24.26 & 6.53 & 24.7 \\
\hline $\begin{array}{r}\text { Exact and Earth } \\
\text { Sciences }\end{array}$ & 4.94 & 21.67 & 3.58 & 18.57 & 1.98 & 13.92 & 1.44 & 11.93 & 7.86 & 26.91 & 5.9 & 23.56 \\
\hline Human Sciences & 7.93 & 27.02 & 7.81 & 26.83 & 9.67 & 29.55 & 9.5 & 29.32 & 6.23 & 24.16 & 5.97 & 23.69 \\
\hline $\begin{array}{r}\text { Applied Social } \\
\text { Sciences }\end{array}$ & 19.85 & 39.89 & 20.46 & 40.34 & 19.86 & 39.9 & 20.91 & 40.67 & 19.84 & 39.88 & 19.97 & 39.98 \\
\hline Engineering & 20.41 & 40.3 & 20.75 & 40.55 & 8.67 & 28.15 & 8.98 & 28.59 & 31.94 & 46.63 & 33.57 & 47.23 \\
\hline Linguistics and Arts & 11.56 & 31.98 & 11.83 & 32.29 & 14.53 & 35.25 & 14.75 & 35.47 & 8.64 & 28.1 & 8.64 & 28.1 \\
\hline Health & 27.74 & 44.77 & 27.92 & 44.86 & 36.42 & 48.12 & 35.72 & 47.92 & 19.21 & 39.39 & 19.43 & 39.56 \\
\hline Entrance shift & 82.78 & 37.76 & 82.73 & 37.8 & 82.87 & 37.68 & 83.52 & 37.1 & 82.68 & 37.84 & 81.86 & 38.54 \\
\hline $\begin{array}{l}\text { Final Entrance Score } \\
\text { (Vestibular Score) }\end{array}$ & 1.06 & 0.88 & -0.45 & 0.56 & 1.03 & 0.87 & -0.46 & 0.55 & 1.09 & 0.88 & -0.44 & 0.57 \\
\hline \multicolumn{13}{|l|}{$\begin{array}{l}\text { 1st term performance } \\
\text { indicators }\end{array}$} \\
\hline GPA & 3.38 & 1.18 & 3.17 & 1.18 & 3.56 & 1.07 & 3.37 & 1.09 & 3.2 & 1.25 & 2.95 & 1.23 \\
\hline \multicolumn{13}{|l|}{$\begin{array}{l}\text { Number of credit } \\
\text { points related to: }\end{array}$} \\
\hline Credits attempted & 22.06 & 4.09 & 21.98 & 3.86 & 22.26 & 4.25 & 22.17 & 3.89 & 21.88 & 3.93 & 21.77 & 3.83 \\
\hline Credits earned & 19.68 & 6.85 & 19.01 & 6.89 & 20.55 & 6.36 & 19.96 & 6.36 & 18.84 & 7.2 & 17.97 & 7.27 \\
\hline Credits cancelled & 0.99 & 4.22 & 1.03 & 4.17 & 0.81 & 3.79 & 0.87 & 3.8 & 1.17 & 4.6 & 1.2 & 4.53 \\
\hline Credits failed & 1.38 & 3.83 & 1.93 & 4.41 & 0.89 & 3.04 & 1.33 & 3.68 & 1.85 & 4.42 & 2.58 & 5.01 \\
\hline $\begin{array}{l}\text { Percentage of } \\
\text { students with first } \\
\text { term or University } \\
\text { registration cancelled }\end{array}$ & 4.43 & 20.57 & 4.09 & 19.81 & 3.35 & 18 & 3.23 & 17.69 & 5.48 & 22.76 & 5.03 & 21.85 \\
\hline $\begin{array}{l}\text { Number of subjects } \\
\text { with enough } \\
\text { attendance in } \\
\text { classroom }\end{array}$ & 5.19 & 1.8 & 5.16 & 1.73 & 5.37 & 1.8 & 5.32 & 1.74 & 5.01 & 1.78 & 4.99 & 1.71 \\
\hline Number of students & & 29,301 & & 29,087 & & 14,525 & & 15,162 & & 14,776 & & 13,925 \\
\hline
\end{tabular}

Source: Academic Registration and Control Department - Universidade Federal de Minas Gerais (DRCA - UFMG). 
Table 5: Regression Discontinuity Manipulation Test using local polynomial density estimation

\begin{tabular}{|c|c|c|c|c|c|c|}
\hline \multirow[b]{2}{*}{ Specifications } & \multicolumn{2}{|c|}{ All students } & \multicolumn{2}{|c|}{ Female students } & \multicolumn{2}{|c|}{ Male students } \\
\hline & $\begin{array}{l}\text { Left of } \\
\text { cutoff }\end{array}$ & $\begin{array}{l}\text { Right of } \\
\text { cutoff }\end{array}$ & $\begin{array}{l}\text { Left of } \\
\text { cutoff }\end{array}$ & $\begin{array}{l}\text { Right of } \\
\text { cutoff }\end{array}$ & $\begin{array}{l}\text { Left of } \\
\text { cutoff }\end{array}$ & $\begin{array}{l}\text { Right of } \\
\text { cutoff }\end{array}$ \\
\hline Sample size & 26652 & 31736 & 13974 & 15713 & 12678 & 16023 \\
\hline $\begin{array}{l}\text { Effective sample size (within } \\
\text { bandwidth) }\end{array}$ & 7719 & 7503 & 4499 & 4260 & 4322 & 4077 \\
\hline $\begin{array}{l}\text { Order of the polynomial used } \\
\text { for density estimation }\end{array}$ & 2 & 2 & 2 & 2 & 2 & 2 \\
\hline $\begin{array}{l}\text { Order of the polynomial used } \\
\text { for bias-correction estimation }\end{array}$ & 3 & 3 & 3 & 3 & 3 & 3 \\
\hline $\begin{array}{l}\text { Bandwidth (h) used to } \\
\text { construct the density } \\
\text { estimators }\end{array}$ & 0.335 & 0.335 & 0.372 & 0.372 & 0.388 & 0.388 \\
\hline Manipulation Test Method & $\begin{array}{c}\mathrm{T}- \\
\text { statistic }\end{array}$ & P-value & $\begin{array}{c}\mathrm{T}- \\
\text { statistic }\end{array}$ & P-value & $\begin{array}{c}\mathrm{T}- \\
\text { statistic }\end{array}$ & P-value \\
\hline Conventional test statistic & -1.1503 & 0.2500 & 0.0703 & 0.9439 & -1.4398 & 0.1499 \\
\hline Robust bias-corrected statistic & -0.6790 & 0.4971 & 0.3603 & 0.7186 & -1.0506 & 0.2934 \\
\hline
\end{tabular}

Source: Academic Registration and Control Department - Universidade Federal de Minas Gerais (DRCA - UFMG). 
Table 6: Balance of Covariates at the Cutoff - UFMG students with University admission between 1995-2013

(to be continued)

\begin{tabular}{|c|c|c|c|c|c|c|}
\hline \multirow[b]{2}{*}{ Characteristic } & \multicolumn{2}{|c|}{ All students } & \multicolumn{2}{|c|}{ Female students } & \multicolumn{2}{|c|}{ Male students } \\
\hline & $\begin{array}{l}\text { RD } \\
\text { Effect }\end{array}$ & $\begin{array}{l}\text { Robust } \\
\text { p-value }\end{array}$ & RD Effect & $\begin{array}{l}\text { Robust } \\
\text { p-value }\end{array}$ & RD Effect & $\begin{array}{l}\text { Robust } \\
\text { p-value }\end{array}$ \\
\hline Sex & 0.017 & 0.238 & - & - & - & - \\
\hline Age & -0.197 & 0.158 & 0.009 & 0.887 & -0.332 & 0.089 \\
\hline \multicolumn{7}{|l|}{ Place of residence } \\
\hline Outside Belo Horizonte & -0.003 & 0.901 & 0.000 & 0.998 & -0.006 & 0.833 \\
\hline Lives in Belo Horizonte & 0.003 & 0.960 & 0.000 & 0.981 & 0.005 & 0.912 \\
\hline Missing information & 0.000 & 0.686 & 0.000 & 0.734 & 0.001 & 0.641 \\
\hline \multicolumn{7}{|l|}{ Father education } \\
\hline $\begin{array}{r}\text { Did not completed Elementary } \\
\text { school }\end{array}$ & 0.002 & 0.886 & 0.029 & 0.074 & -0.040 & 0.030 \\
\hline Completed Elementary school & 0.005 & 0.729 & 0.012 & 0.323 & -0.002 & 0.819 \\
\hline Completed High school & -0.008 & 0.523 & -0.009 & 0.790 & -0.004 & 0.849 \\
\hline Completed College & -0.001 & 0.911 & -0.030 & 0.168 & 0.033 & 0.157 \\
\hline Missing information & 0.001 & 0.920 & -0.005 & 0.363 & 0.007 & 0.319 \\
\hline \multicolumn{7}{|l|}{ Mother education } \\
\hline $\begin{array}{r}\text { Did not completed Elementary } \\
\text { school }\end{array}$ & 0.009 & 0.551 & 0.021 & 0.252 & -0.004 & 0.695 \\
\hline Completed Elementary school & -0.001 & 0.941 & -0.004 & 0.846 & 0.005 & 0.796 \\
\hline Completed High school & -0.005 & 0.687 & -0.016 & 0.405 & 0.006 & 0.841 \\
\hline Completed College & -0.006 & 0.892 & -0.008 & 0.849 & 0.001 & 0.834 \\
\hline Missing information & 0.002 & 0.479 & 0.003 & 0.420 & 0.002 & 0.648 \\
\hline \multicolumn{7}{|l|}{$\begin{array}{l}\text { Family income (in minimum } \\
\text { wages) }\end{array}$} \\
\hline Up to 2 & 0.000 & 0.998 & 0.007 & 0.463 & -0.013 & 0.208 \\
\hline More than 2 to 5 & 0.028 & 0.045 & 0.048 & 0.018 & 0.005 & 0.804 \\
\hline More than 5 to 10 & -0.004 & 0.923 & -0.017 & 0.515 & 0.008 & 0.595 \\
\hline More than 10 to 15 & -0.019 & 0.079 & -0.040 & 0.020 & -0.001 & 0.927 \\
\hline More than 15 to 20 & -0.012 & 0.194 & 0.008 & 0.444 & -0.030 & 0.021 \\
\hline More than 20 & 0.006 & 0.794 & -0.013 & 0.396 & 0.019 & 0.231 \\
\hline Missing information & 0.004 & 0.096 & 0.002 & 0.776 & 0.009 & 0.022 \\
\hline \multicolumn{7}{|l|}{ Work } \\
\hline Did not work & 0.022 & 0.087 & 0.026 & 0.141 & 0.018 & 0.414 \\
\hline Yes, up to 20 hours a week & -0.018 & 0.053 & -0.027 & 0.048 & -0.002 & 0.944 \\
\hline $\begin{array}{r}\text { Yes, more than } 20 \text { hours a } \\
\text { week }\end{array}$ & -0.007 & 0.412 & 0.007 & 0.781 & -0.022 & 0.193 \\
\hline Missing information & 0.004 & 0.077 & 0.002 & 0.672 & 0.009 & 0.034 \\
\hline \multicolumn{7}{|l|}{ Contribution to family income } \\
\hline $\begin{array}{r}\text { Did not work, did not } \\
\text { contributed }\end{array}$ & 0.006 & 0.518 & 0.008 & 0.494 & 0.014 & 0.551 \\
\hline Worked, did not contributed & -0.006 & 0.331 & 0.003 & 0.756 & -0.017 & 0.128 \\
\hline Worked, contributed partially & 0.004 & 0.775 & -0.002 & 0.706 & 0.002 & 0.817 \\
\hline Worked, main responsible & -0.008 & 0.115 & -0.004 & 0.352 & -0.009 & 0.343 \\
\hline Missing information & 0.003 & 0.366 & -0.002 & 0.588 & 0.011 & 0.064 \\
\hline
\end{tabular}


Table 6: Balance of Covariates at the Cutoff - UFMG students with University admission between 1995-2013

\begin{tabular}{|c|c|c|c|c|c|c|}
\hline \multirow[b]{2}{*}{ Characteristic } & \multicolumn{2}{|c|}{ All students } & \multicolumn{2}{|c|}{ Female students } & \multicolumn{2}{|c|}{ Male students } \\
\hline & RD Effect & $\begin{array}{l}\text { Robust } \\
\text { p-value }\end{array}$ & RD Effect & $\begin{array}{l}\text { Robust } \\
\text { p-value }\end{array}$ & RD Effect & $\begin{array}{l}\text { Robust } \\
\text { p-value }\end{array}$ \\
\hline \multicolumn{7}{|l|}{ Number of family members } \\
\hline 1 & -0.008 & 0.099 & -0.017 & 0.012 & -0.002 & 0.711 \\
\hline 2 or 3 & 0.011 & 0.477 & 0.028 & 0.151 & -0.001 & 0.905 \\
\hline 4 or 5 & -0.006 & 0.670 & -0.022 & 0.285 & 0.014 & 0.457 \\
\hline 6 or more & -0.002 & 0.796 & 0.009 & 0.500 & -0.015 & 0.322 \\
\hline Missing information & 0.005 & 0.037 & 0.000 & 0.715 & 0.009 & 0.010 \\
\hline \multicolumn{7}{|l|}{ Type of school } \\
\hline Private & 0.000 & 0.951 & -0.024 & 0.308 & 0.025 & 0.251 \\
\hline Federal public school & -0.016 & 0.083 & -0.007 & 0.436 & -0.017 & 0.228 \\
\hline State/Municipal public school & 0.016 & 0.280 & 0.042 & 0.065 & -0.011 & 0.671 \\
\hline Missing information & -0.001 & 0.824 & 0.000 & 0.854 & -0.001 & 0.859 \\
\hline \multicolumn{7}{|l|}{ School shift (High school)) } \\
\hline Night & 0.001 & 0.913 & 0.021 & 0.066 & -0.016 & 0.272 \\
\hline Day & -0.001 & 0.891 & -0.020 & 0.079 & 0.016 & 0.281 \\
\hline Missing information & 0.000 & 0.690 & 0.000 & 0.853 & 0.000 & 0.872 \\
\hline \multicolumn{7}{|l|}{ College preparatory course } \\
\hline Yes & -0.009 & 0.443 & -0.012 & 0.469 & -0.009 & 0.562 \\
\hline No & 0.009 & 0.464 & 0.012 & 0.464 & 0.008 & 0.618 \\
\hline Missing information & 0.000 & 0.964 & 0.000 & 0.797 & 0.001 & 0.582 \\
\hline \multicolumn{7}{|l|}{ Previous entrance exams } \\
\hline No & -0.003 & 0.859 & 0.003 & 0.721 & -0.010 & 0.500 \\
\hline $\begin{array}{r}\text { Yes, has College diploma or is } \\
\text { enrolled in College }\end{array}$ & -0.006 & 0.429 & -0.010 & 0.421 & -0.002 & 0.875 \\
\hline Yes, other situation & 0.006 & 0.621 & 0.004 & 0.760 & 0.005 & 0.762 \\
\hline Missing information & 0.001 & 0.227 & 0.001 & 0.633 & 0.003 & 0.120 \\
\hline \multicolumn{7}{|l|}{ Program area } \\
\hline $\begin{array}{r}\text { Agrarian, Biological and } \\
\text { Physiological sciences }\end{array}$ & 0.003 & 0.778 & 0.009 & 0.508 & -0.004 & 0.686 \\
\hline Exact and Earth sciences & -0.002 & 0.547 & 0.000 & 0.821 & 0.000 & 0.778 \\
\hline Human sciences & 0.005 & 0.707 & -0.003 & 0.821 & 0.015 & 0.166 \\
\hline Applied Social sciences & 0.003 & 0.668 & -0.015 & 0.345 & 0.023 & 0.159 \\
\hline Engineering & -0.012 & 0.349 & -0.016 & 0.211 & 0.002 & 0.952 \\
\hline Linguistics and Arts & 0.003 & 0.727 & 0.005 & 0.761 & -0.001 & 0.986 \\
\hline Health & -0.007 & 0.635 & 0.018 & 0.366 & -0.049 & 0.016 \\
\hline Entrance shift & -0.002 & 0.925 & -0.004 & 0.943 & -0.008 & 0.502 \\
\hline Number of students & \multicolumn{2}{|c|}{58,388} & \multicolumn{2}{|c|}{29,687} & \multicolumn{2}{|c|}{28,701} \\
\hline
\end{tabular}

Source: Academic Registration and Control Department - Universidade Federal de Minas Gerais (DRCA - UFMG). 
TABLE 7: Effects of enrollment in the first class on students performance indicators in their first semester - UFMG students with University admission between 1995-2013 by sex

\begin{tabular}{|c|c|c|c|c|c|c|c|c|c|}
\hline \multirow[b]{2}{*}{ Characteristic } & \multicolumn{3}{|c|}{ All students } & \multicolumn{3}{|c|}{ Female students } & \multicolumn{3}{|c|}{ Male students } \\
\hline & $\begin{array}{l}\text { Reduced } \\
\text { form }\end{array}$ & Fuzzy & $\begin{array}{l}\text { Fuzzy with } \\
\text { covariates }\end{array}$ & $\begin{array}{l}\text { Reduced } \\
\text { form }\end{array}$ & Fuzzy & $\begin{array}{l}\text { Fuzzy with } \\
\text { covariates }\end{array}$ & $\begin{array}{l}\text { Reduced } \\
\text { form }\end{array}$ & Fuzzy & $\begin{array}{l}\text { Fuzzy with } \\
\text { covariates }\end{array}$ \\
\hline \multirow[t]{3}{*}{ GPA } & $\begin{array}{c}- \\
0.122^{* *}\end{array}$ & $\begin{array}{c}- \\
0.138^{* *}\end{array}$ & & $\begin{array}{c}- \\
0.186^{* *}\end{array}$ & $\begin{array}{c}- \\
0.210 * *\end{array}$ & $-0.205^{* *}$ & -0.069 & -0.078 & -0.087 \\
\hline & {$[0.040]$} & {$[0.045]$} & {$[0.041]$} & [0.049] & {$[0.055]$} & {$[0.053]$} & [0.056] & [0.064] & {$[0.060]$} \\
\hline & \multicolumn{3}{|c|}{58,384} & \multicolumn{3}{|c|}{29,685} & \multicolumn{3}{|c|}{28,699} \\
\hline \multirow{3}{*}{$\begin{array}{l}\text { Number of credits } \\
\text { attempted }\end{array}$} & -0.07 & -0.079 & -0.097 & 0.009 & 0.01 & -0.021 & -0.215 & -0.245 & -0.181 \\
\hline & {$[0.134]$} & [0.150] & [0.133] & {$[0.176]$} & [0.196] & [0.168] & [0.203] & {$[0.230]$} & [0.196] \\
\hline & \multicolumn{3}{|c|}{58,371} & \multicolumn{3}{|c|}{29,682} & \multicolumn{3}{|c|}{28,689} \\
\hline \multirow[t]{3}{*}{$\begin{array}{l}\text { Number of credits } \\
\text { earned }\end{array}$} & $-0.533^{*}$ & $-0.603 *$ & $-0.693 * *$ & $-0.497+$ & $-0.558+$ & $-0.604^{*}$ & $-0.648+$ & $-0.738+$ & $-0.681+$ \\
\hline & {$[0.241]$} & {$[0.271]$} & [0.249] & {$[0.292]$} & {$[0.326]$} & {$[0.307]$} & {$[0.369]$} & {$[0.418]$} & {$[0.375]$} \\
\hline & \multicolumn{3}{|c|}{58,388} & \multicolumn{3}{|c|}{29,687} & \multicolumn{3}{|c|}{28,701} \\
\hline \multirow[t]{3}{*}{$\begin{array}{l}\text { Number of credits } \\
\text { cancelled }\end{array}$} & $0.474^{* *}$ & $0.538^{* *}$ & $0.575^{* *}$ & $0.282+$ & $0.315+$ & $0.334+$ & $0.677^{* *}$ & $0.772 * *$ & $0.800 * *$ \\
\hline & {$[0.154]$} & {$[0.174]$} & {$[0.173]$} & {$[0.166]$} & [0.185] & {$[0.188]$} & [0.243] & [0.277] & {$[0.270]$} \\
\hline & \multicolumn{3}{|c|}{58,388} & \multicolumn{3}{|c|}{29,687} & \multicolumn{3}{|c|}{28,701} \\
\hline \multirow[t]{3}{*}{$\begin{array}{l}\text { Number of credits } \\
\text { failed }\end{array}$} & -0.028 & -0.031 & -0.008 & 0.202 & 0.227 & 0.23 & -0.317 & -0.361 & -0.371 \\
\hline & {$[0.131]$} & {$[0.147]$} & {$[0.139]$} & [0.163] & [0.182] & [0.176] & {$[0.255]$} & [0.289] & {$[0.281]$} \\
\hline & \multicolumn{3}{|c|}{58,388} & \multicolumn{3}{|c|}{29,687} & \multicolumn{3}{|c|}{28,701} \\
\hline \multicolumn{10}{|l|}{$\begin{array}{l}\% \text { of students with } \\
\text { first term or } \\
\text { University } \\
\text { registration cancelled }\end{array}$} \\
\hline se & {$[0.007]$} & [0.008] & {$[0.008]$} & {$[0.008]$} & [0.009] & [0.009] & [0.012] & [0.013] & {$[0.013]$} \\
\hline$N$ & \multicolumn{3}{|c|}{58,384} & \multicolumn{3}{|c|}{29,685} & \multicolumn{3}{|c|}{28,699} \\
\hline \multirow{3}{*}{$\begin{array}{l}\text { Number of subjects } \\
\text { with enough } \\
\text { attendance }\end{array}$} & $-0.103+$ & $-0.116+$ & $-0.151 *$ & -0.036 & -0.04 & -0.074 & $-0.175^{*}$ & $-0.199 *$ & $-0.225^{*}$ \\
\hline & [0.059] & {$[0.066]$} & {$[0.064]$} & {$[0.073]$} & [0.082] & {$[0.081]$} & [0.087] & [0.099] & [0.093] \\
\hline & \multicolumn{3}{|c|}{58,388} & \multicolumn{3}{|c|}{29,687} & \multicolumn{3}{|c|}{28,701} \\
\hline
\end{tabular}

Source: Academic Registration and Control Department - Universidade Federal de Minas Gerais (DRCA - UFMG).

Notes: se=Standard errors. $N=$ Number of students. Statistical significance is represented as following: $+p<0.10, * p<0.05, * * p<0.01$. 
TABLE 8: Effects of enrollment in the first class on students performance indicators in their first semester - UFMG students with University admission between $1995-2013$ by school shift

\begin{tabular}{|c|c|c|c|c|c|c|c|c|c|}
\hline \multirow[b]{2}{*}{ Outcome } & \multicolumn{3}{|c|}{ All students } & \multicolumn{3}{|c|}{ Day shift } & \multicolumn{3}{|c|}{ Night shift } \\
\hline & $\begin{array}{l}\text { Reduced } \\
\text { form }\end{array}$ & Fuzzy & $\begin{array}{l}\text { Fuzzy with } \\
\text { covariates }\end{array}$ & $\begin{array}{l}\text { Reduced } \\
\text { form }\end{array}$ & Fuzzy & $\begin{array}{l}\text { Fuzzy with } \\
\text { covariates }\end{array}$ & $\begin{array}{l}\text { Reduced } \\
\text { form }\end{array}$ & Fuzzy & $\begin{array}{l}\text { Fuzzy with } \\
\text { covariates }\end{array}$ \\
\hline \multirow[t]{3}{*}{ GPA } & $\begin{array}{c}- \\
0.122^{* *}\end{array}$ & $\begin{array}{c}- \\
0.138^{* *}\end{array}$ & & $\begin{array}{c}- \\
0.118^{* *}\end{array}$ & $\begin{array}{c}- \\
0.134^{* *}\end{array}$ & & -0.172 & -0.189 & $-0.211 *$ \\
\hline & {$[0.040]$} & {$[0.045]$} & {$[0.041]$} & {$[0.040]$} & {$[0.045]$} & {$[0.043]$} & [0.105] & {$[0.116]$} & [0.105] \\
\hline & \multicolumn{3}{|c|}{58,384} & \multicolumn{3}{|c|}{48,313} & \multicolumn{3}{|c|}{10,071} \\
\hline \multirow{3}{*}{$\begin{array}{l}\text { Number of credits } \\
\text { attempted }\end{array}$} & -0.07 & -0.079 & -0.097 & -0.045 & -0.051 & -0.05 & -0.218 & -0.24 & -0.218 \\
\hline & [0.134] & {$[0.150]$} & {$[0.133]$} & {$[0.142]$} & [0.161] & [0.142] & {$[0.240]$} & [0.264] & {$[0.234]$} \\
\hline & \multicolumn{3}{|c|}{58,371} & \multicolumn{3}{|c|}{48,302} & \multicolumn{3}{|c|}{10,069} \\
\hline Number of credits earned & $-0.533^{*}$ & $-0.603^{*}$ & $-0.693 * *$ & $-0.542 *$ & $-0.616^{*}$ & $-0.732 * *$ & -0.428 & -0.47 & -0.559 \\
\hline se & {$[0.241]$} & {$[0.271]$} & [0.249] & {$[0.262]$} & [0.295] & {$[0.272]$} & [0.513] & [0.565] & {$[0.504]$} \\
\hline $\mathrm{N}$ & \multicolumn{3}{|c|}{58,388} & \multicolumn{3}{|c|}{48,317} & \multicolumn{3}{|c|}{10,071} \\
\hline \multirow[t]{3}{*}{$\begin{array}{l}\text { Number of credits } \\
\text { cancelled }\end{array}$} & $0.474^{* *}$ & $0.538^{* *}$ & $0.575 * *$ & $0.505^{* *}$ & $0.575^{* *}$ & $0.597^{* *}$ & 0.48 & 0.524 & $0.604+$ \\
\hline & [0.154] & {$[0.174]$} & {$[0.173]$} & {$[0.166]$} & [0.187] & [0.187] & [0.332] & {$[0.363]$} & [0.352] \\
\hline & \multicolumn{3}{|c|}{58,388} & \multicolumn{3}{|c|}{48,317} & \multicolumn{3}{|c|}{10,071} \\
\hline Number of credits failed & -0.028 & -0.031 & -0.008 & 0.003 & 0.004 & 0.042 & -0.171 & -0.189 & -0.234 \\
\hline se & [0.131] & {$[0.147]$} & [0.139] & [0.144] & [0.162] & [0.153] & [0.305] & {$[0.336]$} & [0.341] \\
\hline $\mathrm{N}$ & \multicolumn{3}{|c|}{58,388} & \multicolumn{3}{|c|}{48,317} & \multicolumn{3}{|c|}{10,071} \\
\hline \multirow{3}{*}{$\begin{array}{l}\% \text { of students with first } \\
\text { term or University } \\
\text { registration cancelled }\end{array}$} & $0.021^{* *}$ & $0.024 * *$ & $0.026 * *$ & $0.023^{* *}$ & $0.026 * *$ & $0.027^{* *}$ & 0.014 & 0.015 & 0.02 \\
\hline & {$[0.007]$} & [0.008] & {$[0.008]$} & {$[0.007]$} & {$[0.008]$} & [0.008] & {$[0.018]$} & {$[0.020]$} & {$[0.019]$} \\
\hline & \multicolumn{3}{|c|}{58,384} & \multicolumn{3}{|c|}{48,313} & \multicolumn{3}{|c|}{10,071} \\
\hline \multirow{3}{*}{$\begin{array}{l}\text { Number of subjects with } \\
\text { enough attendance } \\
\text { se } \\
\text { N }\end{array}$} & $-0.103+$ & $-0.116+$ & $-0.151 *$ & -0.105 & $-0.120+$ & $-0.146 *$ & -0.077 & -0.084 & -0.082 \\
\hline & {$[0.059]$} & {$[0.066]$} & {$[0.064]$} & {$[0.064]$} & {$[0.072]$} & [0.068] & [0.140] & [0.154] & [0.139] \\
\hline & \multicolumn{3}{|c|}{58,388} & \multicolumn{3}{|c|}{48,317} & \multicolumn{3}{|c|}{10,071} \\
\hline
\end{tabular}

Source: Academic Registration and Control Department - Universidade Federal de Minas Gerais (DRCA - UFMG).

Notes: se=Standard errors. $\mathrm{N}=$ Number of students. Statistical significance is represented as following: $+p<0.10, * p<0.05, * * p<0.01$ 
TABLE 9: Effects of enrollment in the first class on students performance indicators in their first semester - UFMG students with University admission between 1995-2013 by period of University admission

\begin{tabular}{|c|c|c|c|c|c|c|c|c|c|}
\hline \multirow{2}{*}{ Outcome } & \multicolumn{3}{|c|}{ All students } & \multicolumn{3}{|c|}{$1995-2008$} & \multicolumn{3}{|c|}{ 2009-2013 } \\
\hline & $\begin{array}{l}\text { Reduced } \\
\text { form }\end{array}$ & Fuzzy & $\begin{array}{l}\text { Fuzzy with } \\
\text { covariates }\end{array}$ & $\begin{array}{l}\text { Reduced } \\
\text { form }\end{array}$ & Fuzzy & $\begin{array}{l}\text { Fuzzy with } \\
\text { covariates }\end{array}$ & $\begin{array}{l}\text { Reduced } \\
\text { form }\end{array}$ & Fuzzy & $\begin{array}{l}\text { Fuzzy with } \\
\text { covariates }\end{array}$ \\
\hline \multirow[t]{3}{*}{ GPA } & $\begin{array}{c}- \\
0.122^{* *}\end{array}$ & $\begin{array}{c}- \\
0.138^{* *}\end{array}$ & & $\begin{array}{c}- \\
0.147^{* *}\end{array}$ & $\begin{array}{c}- \\
0.170^{* *}\end{array}$ & $-0.168 * *$ & -0.088 & -0.096 & \\
\hline & {$[0.040]$} & {$[0.045]$} & {$[0.041]$} & {$[0.050]$} & {$[0.057]$} & [0.052] & {$[0.062]$} & [0.069] & {$[0.067]$} \\
\hline & \multicolumn{3}{|c|}{58,384} & \multicolumn{3}{|c|}{34,921} & \multicolumn{3}{|c|}{23,463} \\
\hline \multirow[t]{3}{*}{$\begin{array}{l}\text { Number of credits } \\
\text { attempted }\end{array}$} & -0.07 & -0.079 & -0.097 & -0.036 & -0.042 & -0.053 & -0.163 & -0.178 & -0.255 \\
\hline & [0.134] & {$[0.150]$} & [0.133] & [0.188] & {$[0.215]$} & [0.171] & [0.184] & [0.201] & [0.182] \\
\hline & \multicolumn{3}{|c|}{58,371} & \multicolumn{3}{|c|}{34,914} & \multicolumn{3}{|c|}{23,457} \\
\hline Number of credits earned & $-0.533^{*}$ & $-0.603 *$ & $-0.693 * *$ & $-0.525+$ & $-0.607+$ & $-0.674 *$ & -0.573 & -0.624 & $-0.985^{*}$ \\
\hline se & {$[0.241]$} & {$[0.271]$} & [0.249] & {$[0.302]$} & {$[0.345]$} & {$[0.327]$} & [0.371] & [0.407] & {$[0.386]$} \\
\hline$N$ & \multicolumn{3}{|c|}{58,388} & \multicolumn{3}{|c|}{34,925} & \multicolumn{3}{|c|}{23,463} \\
\hline \multirow[t]{3}{*}{$\begin{array}{l}\text { Number of credits } \\
\text { cancelled }\end{array}$} & $0.474 * *$ & $0.538^{* *}$ & $0.575^{* *}$ & $0.436^{*}$ & $0.504^{*}$ & $0.486 *$ & $0.531^{*}$ & $0.578^{*}$ & $0.689 *$ \\
\hline & [0.154] & {$[0.174]$} & [0.173] & {$[0.186]$} & {$[0.212]$} & {$[0.211]$} & {$[0.247]$} & {$[0.270]$} & {$[0.271]$} \\
\hline & \multicolumn{3}{|c|}{58,388} & \multicolumn{3}{|c|}{34,925} & \multicolumn{3}{|c|}{23,463} \\
\hline Number of credits failed & -0.028 & -0.031 & -0.008 & 0.049 & 0.057 & 0.093 & -0.188 & -0.206 & -0.02 \\
\hline se & [0.131] & [0.147] & [0.139] & {$[0.170]$} & [0.194] & [0.179] & [0.265] & {$[0.290]$} & {$[0.266]$} \\
\hline $\mathrm{N}$ & \multicolumn{3}{|c|}{58,388} & \multicolumn{3}{|c|}{34,925} & \multicolumn{3}{|c|}{23,463} \\
\hline \multirow{3}{*}{$\begin{array}{l}\% \text { of students with first } \\
\text { term or University } \\
\text { registration cancelled }\end{array}$} & $0.021 * *$ & $0.024 * *$ & $0.026 * *$ & $0.024 * *$ & $0.028 * *$ & $0.026 * *$ & 0.017 & 0.018 & $0.023+$ \\
\hline & {$[0.007]$} & {$[0.008]$} & {$[0.008]$} & [0.009] & {$[0.010]$} & [0.010] & {$[0.012]$} & {$[0.013]$} & {$[0.013]$} \\
\hline & \multicolumn{3}{|c|}{58,384} & \multicolumn{3}{|c|}{34,921} & \multicolumn{3}{|c|}{23,463} \\
\hline \multirow{3}{*}{$\begin{array}{l}\text { Number of subjects with } \\
\text { enough attendance } \\
\text { se } \\
\text { N }\end{array}$} & $-0.103+$ & $-0.116+$ & $-0.151 *$ & $-0.147+$ & $-0.171+$ & $-0.168^{*}$ & -0.033 & -0.036 & -0.063 \\
\hline & [0.059] & [0.066] & {$[0.064]$} & [0.078] & [0.090] & [0.075] & [0.101] & [0.111] & [0.100] \\
\hline & \multicolumn{3}{|c|}{58,388} & \multicolumn{3}{|c|}{34,925} & \multicolumn{3}{|c|}{23,463} \\
\hline
\end{tabular}

Source: Academic Registration and Control Department - Universidade Federal de Minas Gerais (DRCA - UFMG).

Notes: se=Standard errors. $\mathrm{N}=$ Number of students. Statistical significance is represented as following: $+p<0.10, * p<0.05,{ }^{* *} p<0.01$. 


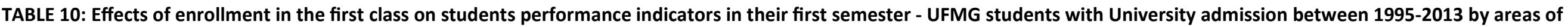
study

(to be continued)

\begin{tabular}{|c|c|c|c|c|c|c|c|c|c|c|c|c|}
\hline \multirow{2}{*}{ Outcome } & \multicolumn{3}{|c|}{ All students } & \multicolumn{3}{|c|}{$\begin{array}{l}\text { Agrarian, Biological and } \\
\text { Physiological Sciences }\end{array}$} & \multicolumn{3}{|c|}{ Exact and Earth Sciences } & \multicolumn{3}{|c|}{ Human Sciences } \\
\hline & $\begin{array}{l}\text { Reduced } \\
\text { form }\end{array}$ & Fuzzy & $\begin{array}{c}\text { Fuzzy } \\
\text { with } \\
\text { covariates } \\
\end{array}$ & $\begin{array}{l}\text { Reduced } \\
\text { form }\end{array}$ & Fuzzy & $\begin{array}{c}\text { Fuzzy } \\
\text { with } \\
\text { covariates } \\
\end{array}$ & $\begin{array}{l}\text { Reduced } \\
\text { form }\end{array}$ & Fuzzy & $\begin{array}{c}\text { Fuzzy } \\
\text { with } \\
\text { covariates } \\
\end{array}$ & $\begin{array}{l}\text { Reduced } \\
\text { form }\end{array}$ & Fuzzy & $\begin{array}{c}\text { Fuzzy } \\
\text { with } \\
\text { covariates } \\
\end{array}$ \\
\hline \multirow[t]{3}{*}{ GPA } & $\stackrel{-}{0.122^{* *}}$ & $\stackrel{-}{0.138 * *}$ & $-0.157^{* *}$ & -0.059 & -0.069 & -0.11 & -0.263 & -0.298 & -0.255 & 0.069 & 0.079 & 0.001 \\
\hline & {$[0.040]$} & {$[0.045]$} & {$[0.041]$} & {$[0.120]$} & [0.141] & [0.133] & [0.219] & [0.248] & {$[0.200]$} & {$[0.135]$} & [0.155] & [0.144] \\
\hline & \multicolumn{3}{|c|}{58,384} & \multicolumn{3}{|c|}{4,444} & \multicolumn{3}{|c|}{2,486} & \multicolumn{3}{|c|}{4,595} \\
\hline \multirow[t]{3}{*}{ Number of credits attempted } & -0.07 & -0.079 & -0.097 & -0.308 & -0.356 & 0.063 & -0.277 & -0.314 & -0.486 & 0.11 & 0.126 & -0.259 \\
\hline & [0.134] & {$[0.150]$} & [0.133] & {$[0.468]$} & [0.541] & {$[0.406]$} & {$[0.475]$} & [0.539] & [0.499] & [0.674] & {$[0.775]$} & [0.701] \\
\hline & \multicolumn{3}{|c|}{58,371} & \multicolumn{3}{|c|}{4,442} & \multicolumn{3}{|c|}{2,487} & \multicolumn{3}{|c|}{4,595} \\
\hline \multirow[t]{3}{*}{ Number of credits earned } & $-0.533^{*}$ & $-0.603 *$ & $-0.693 * *$ & -0.386 & -0.453 & -0.24 & $-2.392+$ & $\begin{array}{c}- \\
2.711+\end{array}$ & $-2.799+$ & 0.532 & 0.609 & -0.26 \\
\hline & {$[0.241]$} & {$[0.271]$} & {$[0.249]$} & {$[0.836]$} & {$[0.978]$} & [0.890] & {$[1.291]$} & {$[1.467]$} & {$[1.476]$} & [0.954] & [1.097] & [1.052] \\
\hline & \multicolumn{3}{|c|}{58,388} & \multicolumn{3}{|c|}{4,444} & \multicolumn{3}{|c|}{2,488} & \multicolumn{3}{|c|}{4,595} \\
\hline \multirow[t]{3}{*}{ Number of credits cancelled } & $0.474 * *$ & $0.538 * *$ & $0.575^{* *}$ & 0.34 & 0.397 & 0.422 & 1.033 & 1.162 & 1.109 & 0.125 & 0.142 & 0.392 \\
\hline & [0.154] & [0.174] & [0.173] & [0.372] & [0.433] & [0.423] & [1.032] & [1.165] & [1.269] & [0.473] & [0.544] & [0.520] \\
\hline & \multicolumn{3}{|c|}{58,388} & \multicolumn{3}{|c|}{4,444} & \multicolumn{3}{|c|}{2,488} & \multicolumn{3}{|c|}{4,595} \\
\hline \multirow[t]{3}{*}{ Number of credits failed } & -0.028 & -0.031 & -0.008 & -0.378 & -0.445 & -0.134 & 1.018 & 1.15 & 1.112 & -0.594 & -0.677 & -0.441 \\
\hline & [0.131] & [0.147] & [0.139] & [0.634] & {$[0.746]$} & [0.704] & [0.979] & [1.109] & [1.078] & [0.497] & {$[0.570]$} & [0.546] \\
\hline & \multicolumn{3}{|c|}{58,388} & \multicolumn{3}{|c|}{4,444} & \multicolumn{3}{|c|}{2,488} & \multicolumn{3}{|c|}{4,595} \\
\hline $\begin{array}{l}\% \text { of students with first term or University } \\
\text { registration cancelled }\end{array}$ & $0.021^{* *}$ & $0.024 * *$ & $0.026 * *$ & 0.023 & 0.026 & 0.025 & 0.018 & 0.02 & 0.022 & 0.017 & 0.02 & 0.028 \\
\hline se & [0.007] & {$[0.008]$} & [0.008] & [0.016] & {$[0.019]$} & [0.019] & {$[0.050]$} & {$[0.057]$} & [0.065] & [0.022] & {$[0.025]$} & [0.024] \\
\hline$N$ & & 58,384 & & & 4,444 & & & 2,486 & & & 4,595 & \\
\hline $\begin{array}{l}\text { Number of subjects with enough } \\
\text { attendance }\end{array}$ & $-0.103+$ & $-0.116+$ & $-0.151 *$ & -0.213 & -0.249 & -0.156 & -0.447 & -0.509 & -0.46 & 0.226 & 0.258 & 0.024 \\
\hline 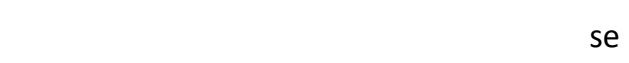 & [0.059] & {$[0.066]$} & {$[0.064]$} & {$[0.175]$} & [0.204] & {$[0.196]$} & [0.329] & {$[0.375]$} & [0.367] & {$[0.268]$} & [0.308] & [0.264] \\
\hline $\mathrm{N}$ & & 58,388 & & & 4,444 & & & 2,488 & & & 4,595 & \\
\hline
\end{tabular}




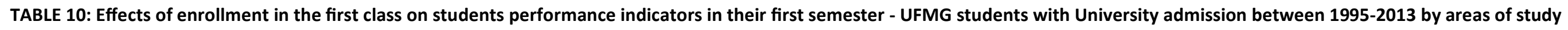

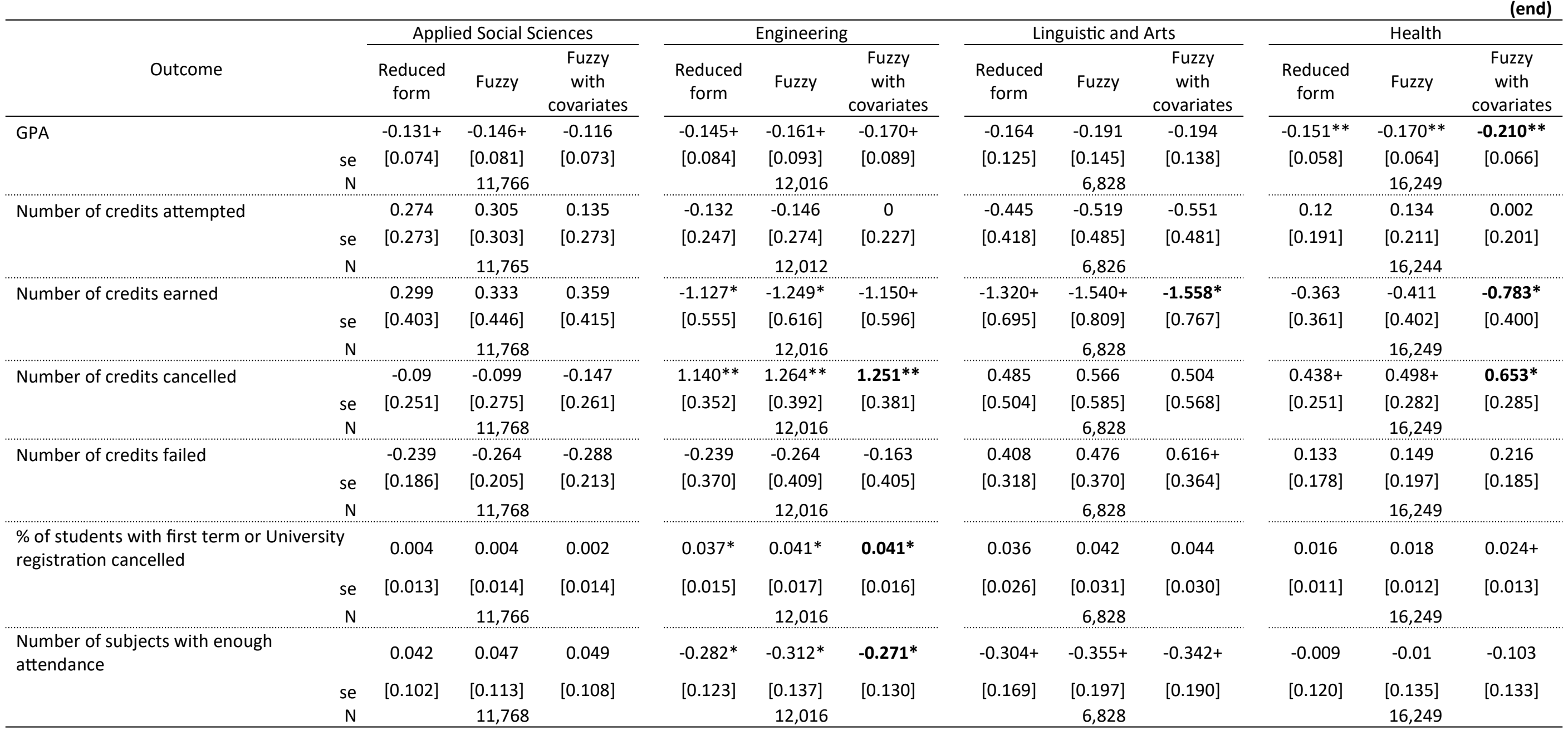

Source: Academic Registration and Control Department - Universidade Federal de Minas Gerais (DRCA - UFMG).

Notes: se=Standard errors. $\mathrm{N}=$ Number of students. Statistical significance is represented as following: $+p<0.10, * p<0.05, * * p<0.01$. 


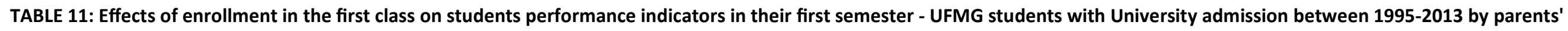
education

\begin{tabular}{|c|c|c|c|c|c|c|c|c|c|c|c|c|}
\hline \multirow[b]{2}{*}{ Outcome } & \multicolumn{3}{|c|}{ All students } & \multicolumn{3}{|c|}{$\begin{array}{l}\text { Both parents with College } \\
\text { Degree }\end{array}$} & \multicolumn{3}{|c|}{$\begin{array}{l}\text { One of the parents with College } \\
\text { Degree }\end{array}$} & \multicolumn{3}{|c|}{$\begin{array}{l}\text { Neither parents with College } \\
\text { Degree }\end{array}$} \\
\hline & $\begin{array}{l}\text { Reduced } \\
\text { form }\end{array}$ & Fuzzy & $\begin{array}{c}\text { Fuzzy } \\
\text { with } \\
\text { covariates }\end{array}$ & $\begin{array}{l}\text { Reduced } \\
\text { form }\end{array}$ & Fuzzy & $\begin{array}{c}\text { Fuzzy } \\
\text { with } \\
\text { covariates }\end{array}$ & $\begin{array}{l}\text { Reduced } \\
\text { form }\end{array}$ & Fuzzy & $\begin{array}{c}\text { Fuzzy } \\
\text { with } \\
\text { covariates } \\
\end{array}$ & $\begin{array}{l}\text { Reduced } \\
\text { form }\end{array}$ & Fuzzy & $\begin{array}{c}\text { Fuzzy } \\
\text { with } \\
\text { covariates }\end{array}$ \\
\hline \multirow{3}{*}{ GPA } & $-0.122 * *$ & $-0.138^{* *}$ & $-0.157 * *$ & 0.012 & 0.014 & 0.003 & $-0.154 *$ & $-0.175^{*}$ & $-0.191 *$ & $-0.190 * *$ & $-0.214^{* *}$ & $-0.236 * *$ \\
\hline & {$[0.040]$} & {$[0.045]$} & {$[0.041]$} & {$[0.071]$} & {$[0.080]$} & {$[0.074]$} & {$[0.075]$} & {$[0.084]$} & {$[0.079]$} & {$[0.061]$} & {$[0.068]$} & {$[0.064]$} \\
\hline & & 58,384 & & & 17,499 & & & 16,345 & & & 24,540 & \\
\hline \multirow[t]{3}{*}{ Number of credits attempted } & -0.07 & -0.079 & -0.097 & $0.401+$ & $0.450+$ & 0.275 & $-0.429+$ & $-0.484+$ & $-0.425+$ & -0.119 & -0.134 & 0.003 \\
\hline & {$[0.134]$} & {$[0.150]$} & [0.133] & [0.229] & {$[0.256]$} & [0.235] & {$[0.245]$} & {$[0.275]$} & {$[0.230]$} & {$[0.200]$} & {$[0.224]$} & {$[0.165]$} \\
\hline & & 58,371 & & & 17,492 & & & 16,342 & & & 24,537 & \\
\hline \multirow[t]{3}{*}{ Number of credits earned } & $-0.533^{*}$ & $-0.603^{*}$ & $-0.693 * *$ & $0.869 *$ & $0.975^{*}$ & $0.963^{*}$ & $-1.331 * *$ & $-1.513^{* *}$ & $-1.553 * *$ & $-1.021 * *$ & $-1.154^{* *}$ & $-1.157 * *$ \\
\hline & {$[0.241]$} & {$[0.271]$} & [0.249] & [0.415] & [0.464] & [0.485] & {$[0.481]$} & {$[0.545]$} & {$[0.520]$} & {$[0.370]$} & {$[0.416]$} & {$[0.373]$} \\
\hline & & 58,388 & & & 17,499 & & & 16,346 & & & 24,543 & \\
\hline \multirow[t]{3}{*}{ Number of credits cancelled } & $0.474 * *$ & $0.538 * *$ & $0.575 * *$ & 0.102 & 0.115 & 0.096 & $0.734 * *$ & $0.836 * *$ & $0.981 * *$ & $0.658 * *$ & $0.744 * *$ & $0.784 * *$ \\
\hline & {$[0.154]$} & [0.174] & {$[0.173]$} & {$[0.241]$} & [0.269] & {$[0.257]$} & {$[0.267]$} & [0.304] & {$[0.298]$} & {$[0.236]$} & {$[0.265]$} & {$[0.263]$} \\
\hline & & 58,388 & & & 17,499 & & & 16,346 & & & 24,543 & \\
\hline \multirow[t]{3}{*}{ Number of credits failed } & -0.028 & -0.031 & -0.008 & $-0.575^{*}$ & $0.647^{-}$ & $-0.572+$ & 0.14 & 0.159 & 0.218 & 0.165 & 0.186 & 0.153 \\
\hline & {$[0.131]$} & {$[0.147]$} & [0.139] & {$[0.275]$} & [0.309] & [0.298] & [0.281] & [0.317] & [0.301] & [0.187] & [0.210] & [0.201] \\
\hline & & 58,388 & & & 17,499 & & & 16,346 & & & 24,543 & \\
\hline $\begin{array}{l}\% \text { of students with first term or University } \\
\text { registration cancelled }\end{array}$ & $0.021^{* *}$ & $0.024 * *$ & $0.026 * *$ & 0.001 & 0.001 & -0.001 & $0.031^{*}$ & $0.035^{*}$ & $0.040 * *$ & $0.031^{* *}$ & $0.035 * *$ & $0.037^{* *}$ \\
\hline se & [0.007] & [0.008] & [0.008] & [0.011] & [0.013] & [0.013] & [0.012] & [0.014] & [0.014] & [0.012] & [0.013] & [0.013] \\
\hline $\mathrm{N}$ & & 58,384 & & & 17,499 & & & 16,345 & & & 24,540 & \\
\hline \multirow[t]{3}{*}{$\begin{array}{l}\text { Number of subjects with enough } \\
\text { attendance }\end{array}$} & $-0.103+$ & $-0.116+$ & $-0.151^{*}$ & 0.104 & 0.117 & 0.104 & -0.141 & -0.159 & $-0.286 *$ & $-0.203^{*}$ & $-0.230 *$ & $-0.244^{*}$ \\
\hline & [0.059] & {$[0.066]$} & [0.064] & [0.106] & [0.118] & [0.111] & [0.104] & [0.117] & [0.120] & [0.094] & [0.106] & [0.100] \\
\hline & & 58,388 & & & 17,499 & & & 16,346 & & & 24,543 & \\
\hline
\end{tabular}

Source: Academic Registration and Control Department - Universidade Federal de Minas Gerais (DRCA - UFMG).

Notes: se=Standard errors. $\mathrm{N}=$ Number of students. Statistical significance is represented as following: $+p<0.10, * p<0.05, * * p<0.01$. 


\subsection{Figures}

FIGURE 1: Final Entrance Score vs. Enrollment in the first class by sex - UFMG students with University admission between 1995-2013
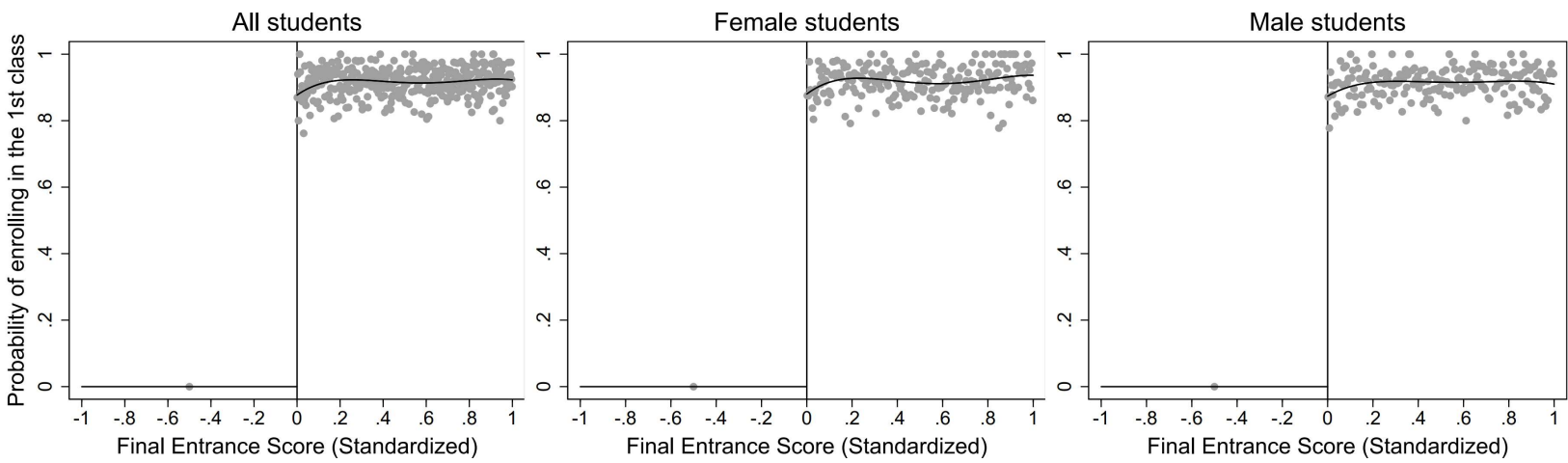

Source: Academic Registration and Control Department - Universidade Federal de Minas Gerais (DRCA - UFMG).

FIGURE 2: Manipulation testing based on density discontinuity by sex - UFMG students with University admission between 1995-2013
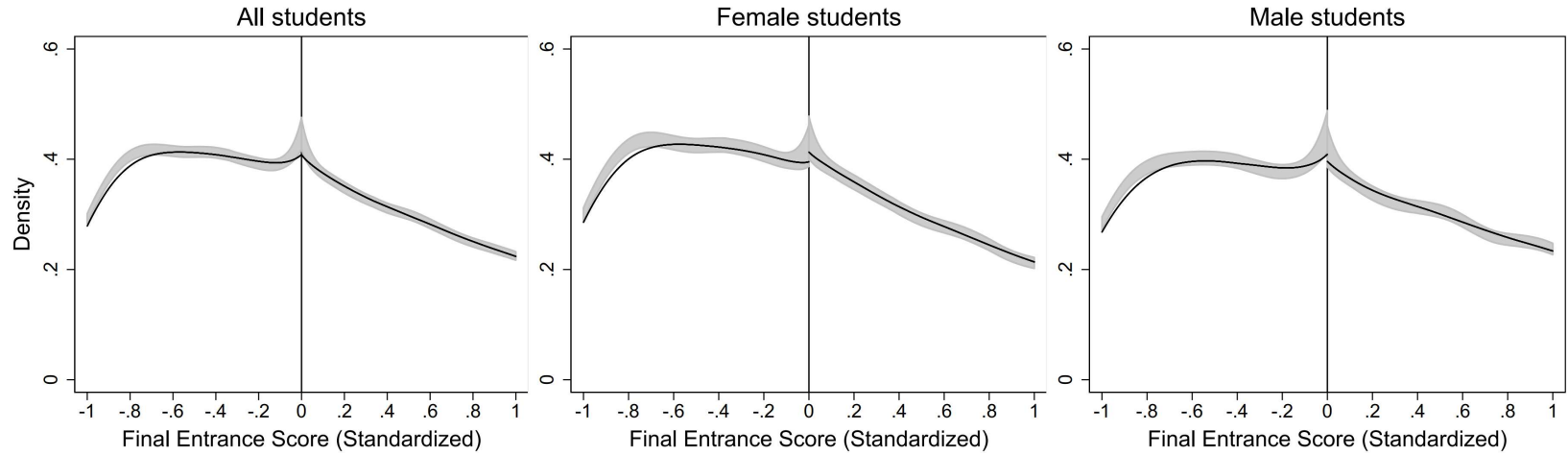

Source: Academic Registration and Control Department - Universidade Federal de Minas Gerais (DRCA - UFMG). 
FIGURE 3: Effects of First Class Enrollment on First semester performance outcomes using different bandwidths - All UFMG students with University admission between 1995-2013

Panel 1 - Different performance indicators: GPA, Final situation of semester, Number of credits taken and Number of Subjects with enough attendance
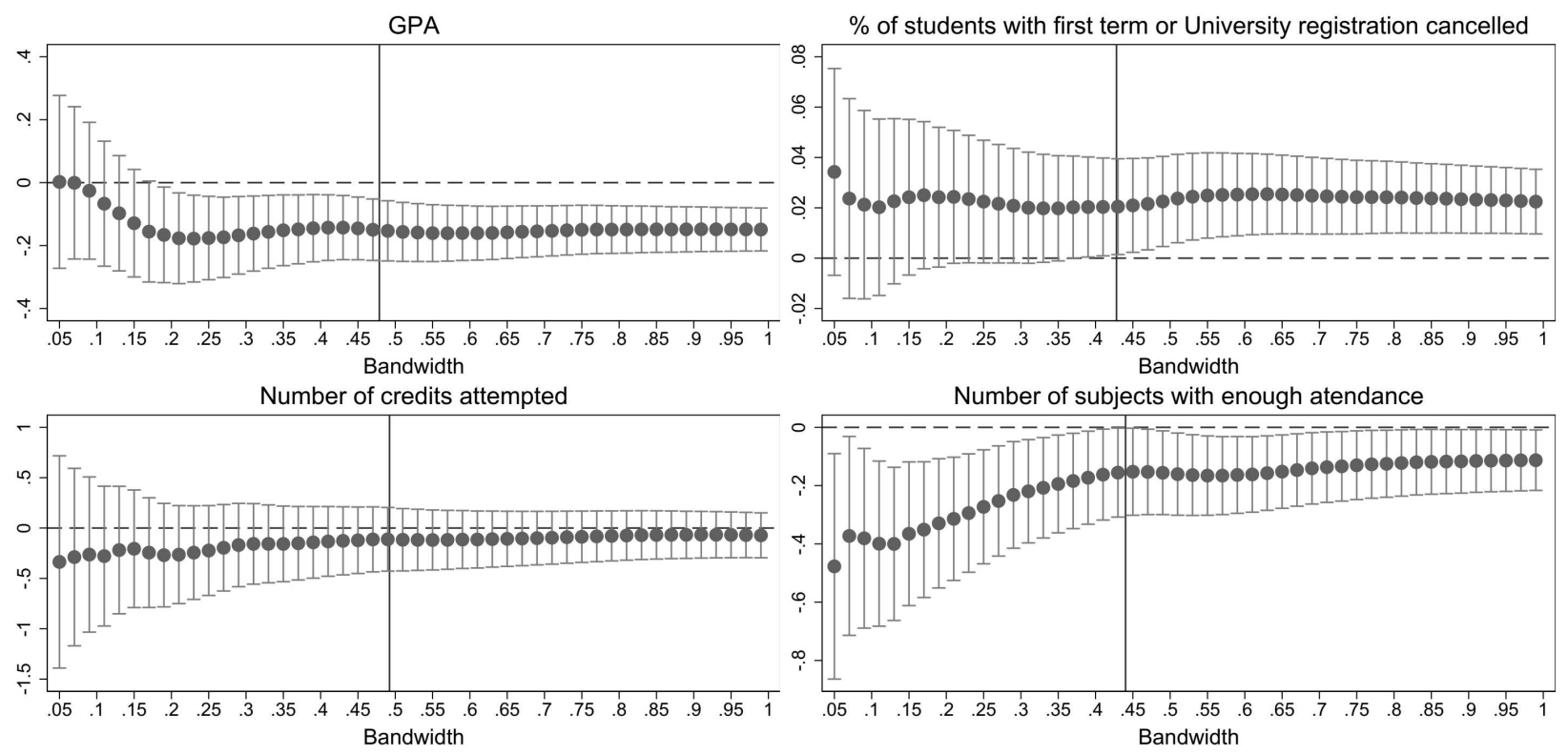

Panel 2 - Final outcomes on the credits taken: Number of Credits Approved, Locked, Canceled and Failed
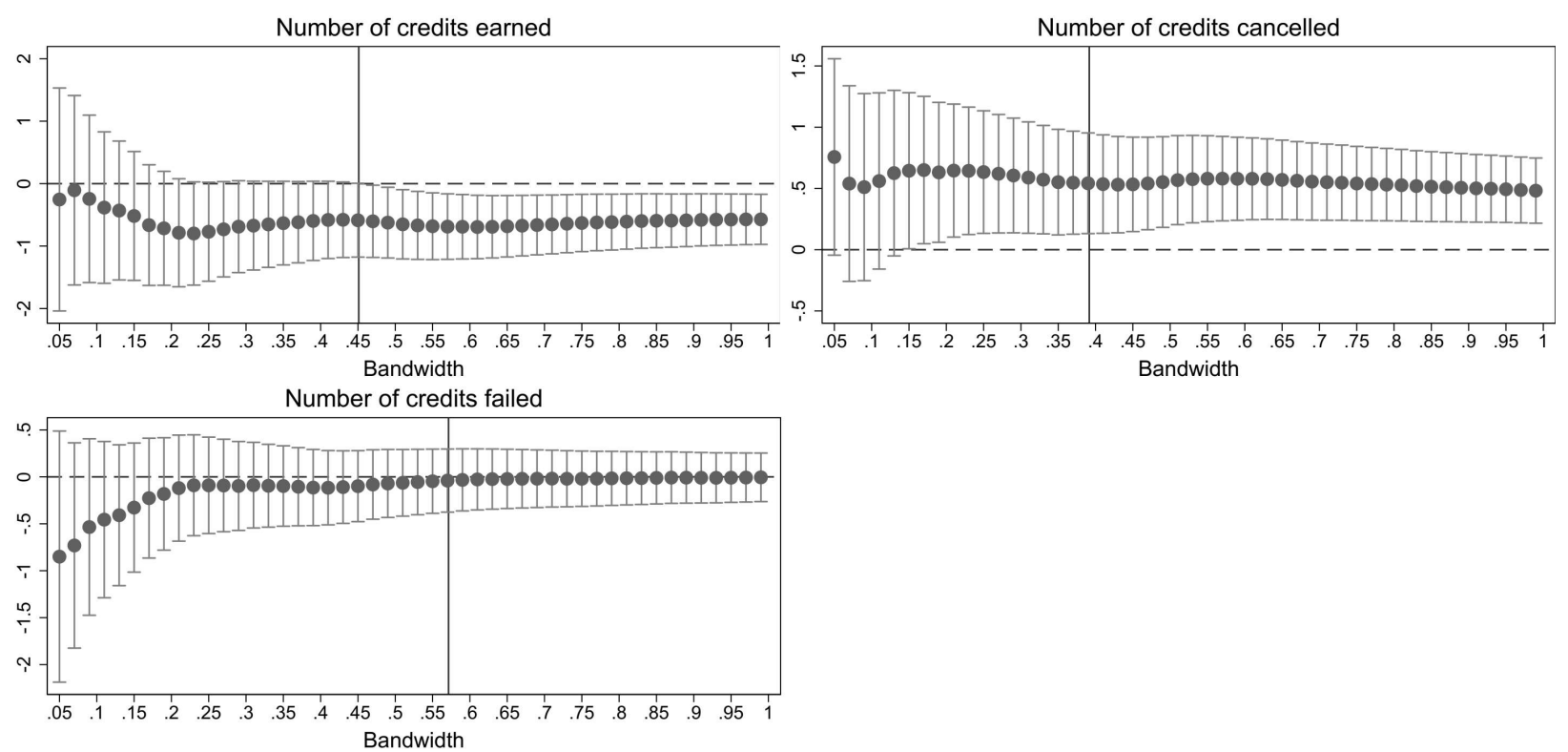

Source: Academic Registration and Control Department - Universidade Federal de Minas Gerais (DRCA - UFMG). 
FIGURE 4: Effects of First Class Enrollment on First semester performance outcomes using different bandwidths Female UFMG students with University admission between 1995-2013

Panel 1 - Different performance indicators: GPA, Final situation of semester, Number of credits taken and Number of Subjects with enough attendance
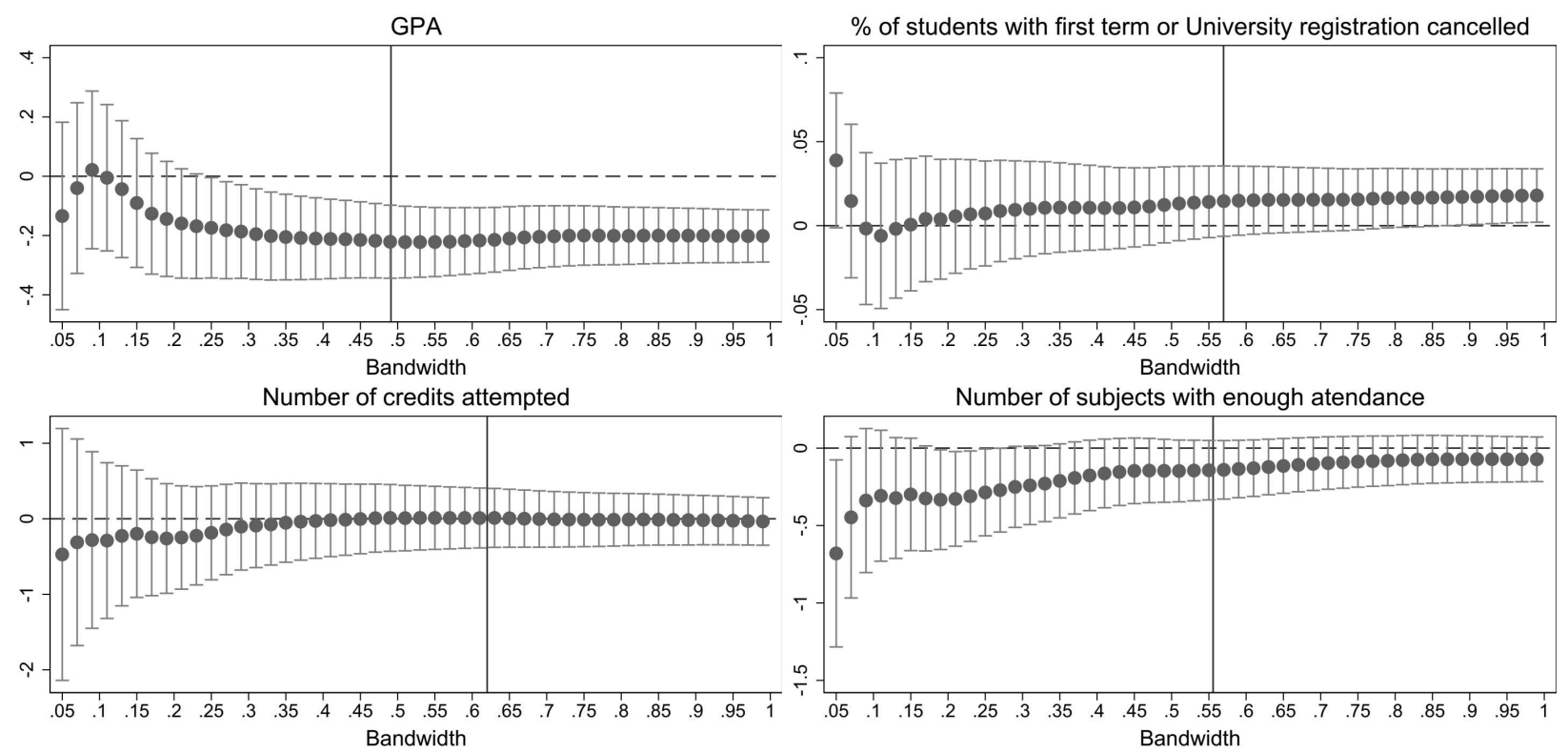

Panel 2 - Final outcomes on the credits taken: Number of Credits Approved, Locked, Canceled and Failed
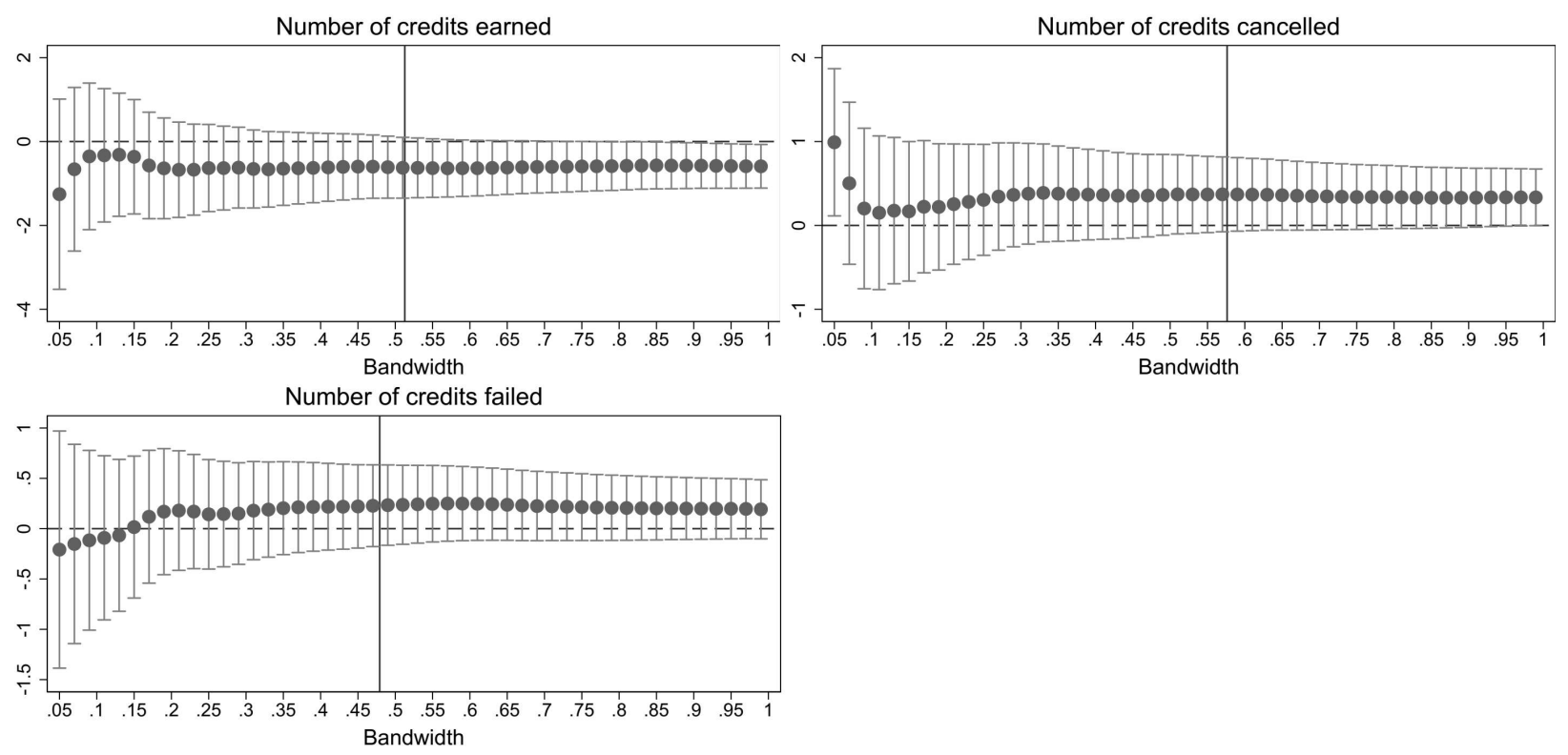

Source: Academic Registration and Control Department - Universidade Federal de Minas Gerais (DRCA - UFMG). 
FIGURE 5: Effects of First Class Enrollment on First semester performance outcomes using different bandwidths Male UFMG students with University admission between 1995-2013

Panel 1 - Different performance indicators: GPA, Final situation of semester, Number of credits taken and Number of Subjects with enough attendance

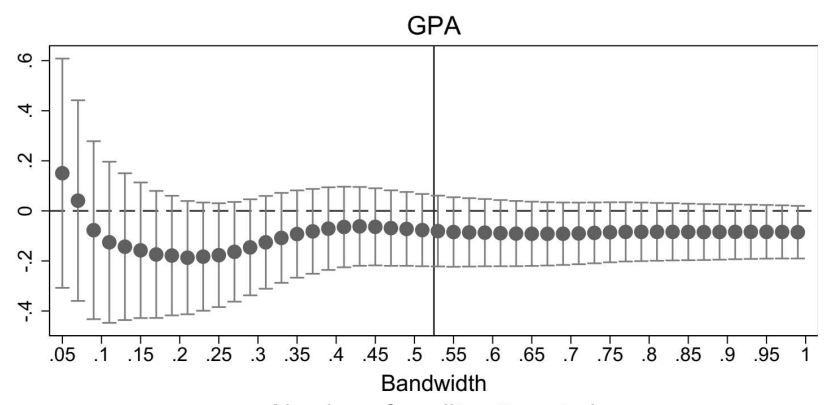

Number of credits attempted

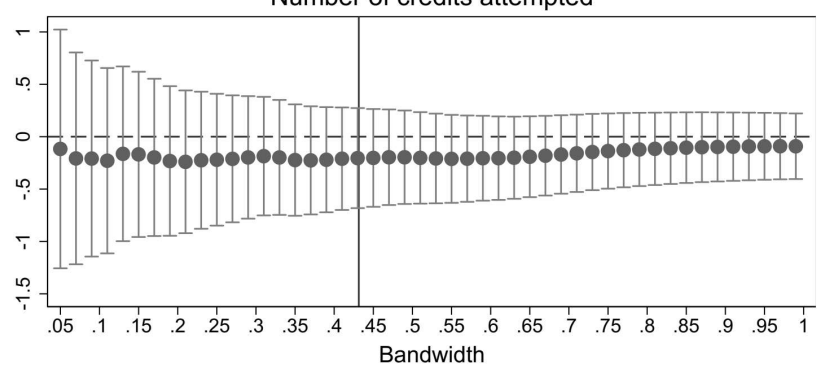

$\%$ of students with first term or University registration cancelled

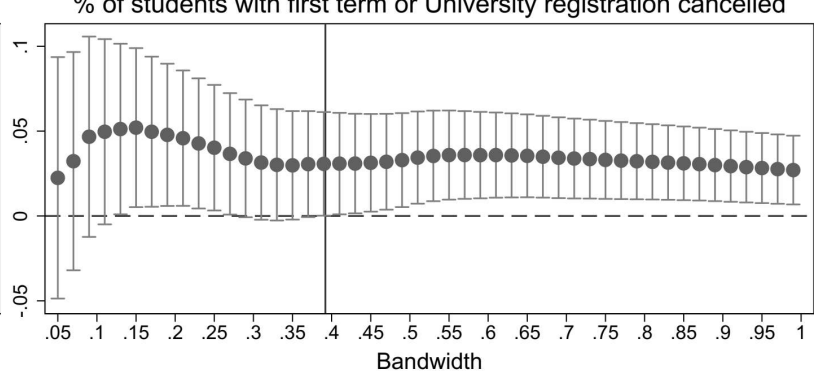

Number of subjects with enough atendance

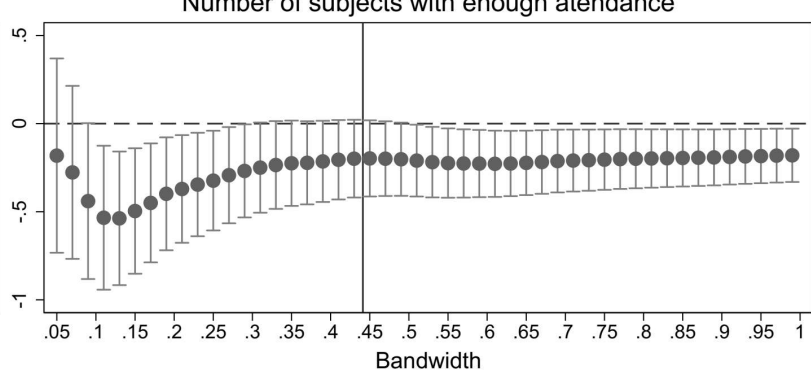

Panel 2 - Final outcomes on the credits taken: Number of Credits Approved, Locked, Canceled and Failed
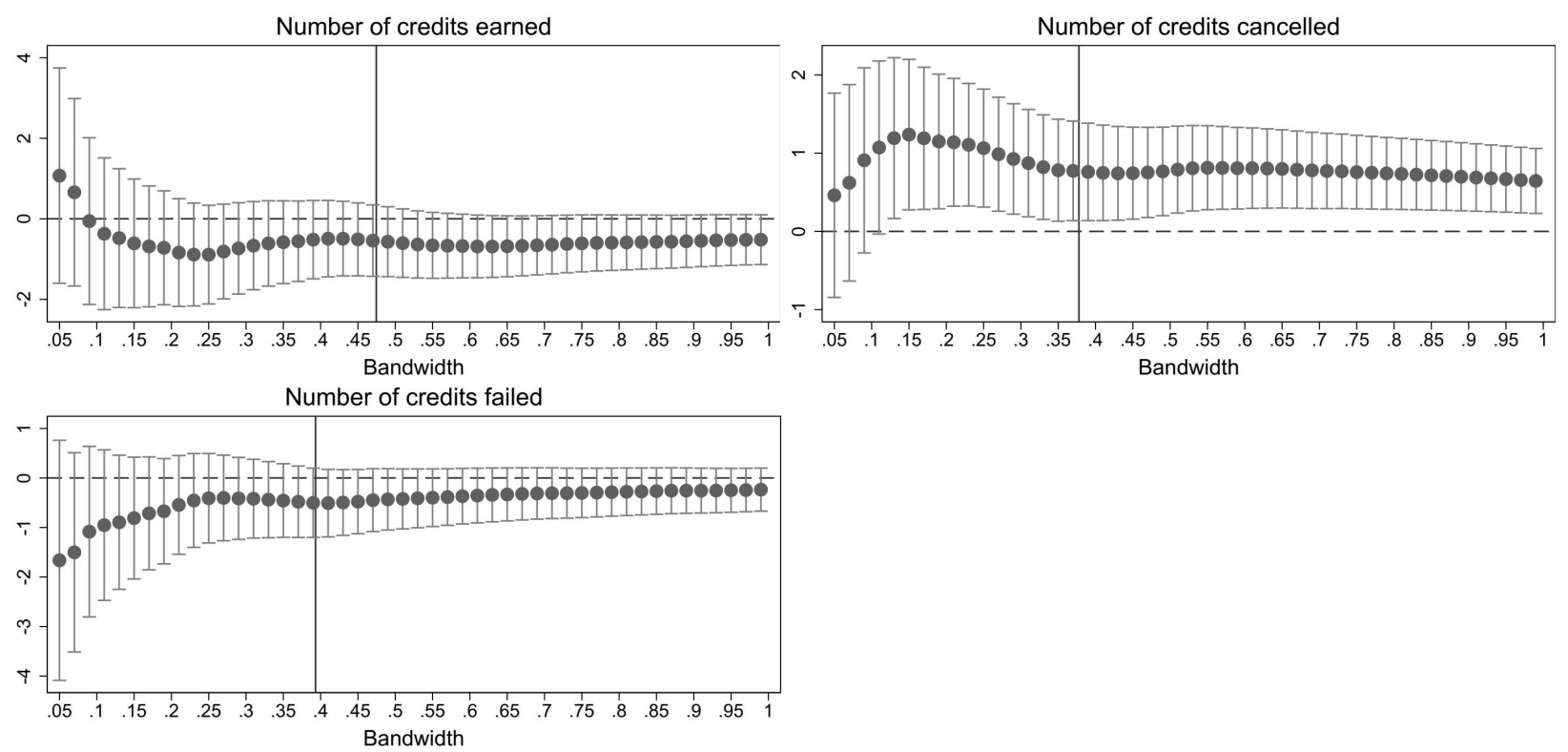

Source: Academic Registration and Control Department - Universidade Federal de Minas Gerais (DRCA - UFMG). 


\section{References}

Androushchak, G., Poldin, O. and Yudkevich, M. (2013). Role of peers in student academic achievement in exogenously formed university groups. Educational Studies, 39:5, 568-581, DOI: 10.1080/03055698.2013.814561.

André, D. de M. (2016). Peer Effects and Academic Performance in Higher Education - A Regression Discontinuity Design Approach. In: André, D. de M. Three essays on applied microeconometrics with spatial effects (Doctoral dissertation).Retrieved from Federal University of Ceara (UFC) Institutional Repository. Available at: http://www.repositorio.ufc.br/bitstream/riufc/19363/1/2016_tese_dmandr\%C3\%A9.pdf. Accessed on: 04/22/2017.

Angrist, J. D. and Pischke, J. S. (2008). Getting a Little Jumpy: Regression Discontinuity Designs. In Angrist, J. D. and Pischke, J. S., Mostly Harmless Econometrics: An Empiricist's Companion. Business Economics, 45(1):75-76.

Asadullah, M., and Chaudhury, N. (2008). Social Interactions And Student Achievement In A Developing Country: An Instrumental Variables Approach. Policy Research Working Papers. http://dx.doi.org/10.1596/1813-9450-4508.

Booij, A.S., Leuven, E., Oosterbeek, H. (2017). Ability peer effects in university: Evidence from a randomized experiment. Review of Economic Studies. Volume 84, Issue 2, Pages 547-578.

Burke, M. A. and Sass, T. R. (2013). Classroom Peer Effects and Student Achievement. Journal of Labor Economics,31(1): 51-82. doi: 10.1086/666653.

Campos, C., Hargreaves Heap, S., and Leite Lopez de Leon, F. (2016). The political influence of peer groups: experimental evidence in the classroom. Oxford Economic Papers, gpw065. http://dx.doi.org/10.1093/oep/gpw065.

Carrell, S. E., Fullerton, R. L., and West, J. E. (2009). Does Your Cohort Matter? Measuring Peer Effects in College Achievement. Journal of Labor Economics, 27(3), 439-464.

Carrell, S.E., Sacerdote, B.I., West, J.E. (2013). From natural variation to optimal policy? The importance of endogenous peer group formation. Econometrica. Volume 81, Issue 3, May 2013, Pages 855-882.

Carrell, Scott E., and Mark L. Hoekstra.(2010). Externalities in the classroom: How children exposed to domestic violence affect everyone's kids. American Economic Journal: Applied Economics 2(1):211-28.

Calonico, S., M. D. Cattaneo and R. Titiunik (2014). Robust nonparametric confidence intervals for regressiondiscontinuity designs. Econometrica 82, 2295-326.

Cattaneo, M.D., Jansson, M., Ma, X. (2020). Simple Local Polynomial Density Estimators, Journal of the American Statistical Association, 115:531, 1449-1455, DOI: 10.1080/01621459.2019.1635480.

Chen, Q., Okediji, T. and Guoqiang, T. (2015). Exploiting Regression-Discontinuity Design to Estimate Peer Effects in College - The Case of Class Attendance. Economics Bulletin, 35(3):1563-1571.

Chetty, R., Friedman, J., Hilger, N., Saez, E., Schanzenbach, D. W. and Yagan, D. (2011). How Does Your Kindergarten Classroom Affect Your Earnings? Evidence from Project Star. The Quarterly Journal of Economics, 126(4): 1593-1660.

Cornelissen, T., Dustmann, C. and Schönberg, U. (2017). Peer Effects in the Workplace. American Economic Review, 107(2): 425-456. 
De Melo, G. (2014). Peer effects identified through social networks: Evidence from Uruguayan schools. Working Papers, Banco de México, No. 2014-05.

DeLay, D., Hanish, L. D., Martin, C. L., and Fabes, R. A. (2016). Peer effects on Head Start children's preschool competency. Developmental Psychology, 52(1), 58-70.

Duflo, E., Dupas, P., and Kremer, M. (2011). Peer Effects, Teacher Incentives, and the Impact of Tracking: Evidence from a Randomized Evaluation in Kenya. American Economic Review, 101(5), 1739-1774. http://dx.doi.org/10.1257/aer.101.5.1739.

Eisenberg, D., Golberstein, E. and Whitlock, J. L. (2014). Peer effects on risky behaviors: New evidence from college roommate assignments. Journal of Health Economics, 33: 126-138.

Elsner, B. and Isphording, I. E. (2018). Rank, Sex, Drugs, and Crime. J. Human Resources, March 31, 2018 53:356-381.

Fortin B, Yazbeck M. (2015). Peer effects, fast food consumption and adolescent weight gain. Journal of Health Economics, 42: 125-138.

Gaviria, A., Raphael, S.(2001). School-based peer effects and juvenile behavior. Review of Economics and Statistics, 83 (2), 257-268.

Graham, B. (2011). Econometric methods for the analysis of assignment problems in the presence of complementarity and social spillovers. In J. Benhabib, M. O. Jacksons and A. Bisin (Eds.), Handbook of Social Economics. Amsterdam: North-Holland.

Hanushek, E., Kain, J., Markman, J., and Rivkin, S. (2003). Does peer ability affect student achievement?. Journal Of Applied Econometrics, 18(5), 527-544. http://dx.doi.org/10.1002/jae.741.

Imbens, G. W., and T. Lemieux.(2008). Regression Discontinuity Designs: A Guide to Practice. Journal of Econometrics, 142(2): 615-35.

Kremer, M. and Levy, D. (2008). Peer Effects and Alcohol Use among College Students. Journal of Economic Perspectives, 22(3): 189-206.

Lee, D. S. and Lemieux, T.(2010). Regression discontinuity designs in economics. Journal of Economic Literature, 48, 281-355.

Lee, D. S. and Lemieux, T.(2015). Regression Discontinuity Designs in Social Sciences. In Regression Analysis and Causal Inference, H. Best and C. Wolf (eds.), Sage.

Marotta, L. (2017). Peer effects in early schooling: Evidence from Brazilian primary schools. International Journal of Educational Research, 82 (2017) 110-123.

Mas, A., and Moretti, E. (2009). Peers at work. American Economic Review, 99, 1: 112-145.

McCrary, J., 2008. Manipulation of the running variable in the regression discontinuity design: a density test. J. Econom. 142 (2), 698-714.

Ministério da Educação (MEC) and Instituto Nacional de Estudos e Pesquisas Educacionais Anísio Teixeira (INEP). (2016). Censo da Educação Superior: Sinopse Estatística da Educação Superior - Graduação. Brasília, DF. Available at: http://portal.inep.gov.br/sinopses-estatisticas-da-educacao-superior. Accessed on: 04/23/2017.

Motte, H. Z. and Oliveira, R. C. (2020). The effect of class assignment on academic performance and the labour market: Evidence from a public federal university in Brazil. WIDER Working Paper Series wp-2020-8, World Institute for Development Economic Research (UNU-WIDER). 
Neidell, M., and Waldfogel, J. (2010). Cognitive and Noncognitive Peer Effects in Early Education. The Review of Economics and Statistics, 92(3): 562-576. doi: 10.1162/REST_a_00012.

Oosterbeek, H. and Ewijk, R. (2014). Gender peer effects in university: Evidence from a randomized experiment. Economics of Education Review. Volume 38, February 2014, Pages 51-63.

Park, H., Behrman, J. R., \& Choi, J. (2018). Do single-sex schools enhance students' STEM (science, technology, engineering, and mathematics) outcomes? Economics of Education Review, 62, 35-47. doi: 10.1016/j.econedurev.2017.10.007.

Poldin, O., P. Simoes, T. P.,Knobel, M. and Yudkevich, M. (2015). Estimation of Peer Effects with Predicted Social Ties: Evidence from two Universities in Brazil and Russia. National Research University. Higher School of Economics. Basic Research Program. Working Papers Series: Education, WP BRP 30/EDU/2015.

Ribas, Rafael Perez; Sampaio, Breno and Trevisan, Giuseppe (2020). Short- and long-term effects of class assignment: Evidence from a flagship university in Brazil. Labour Economics, Volume 64, June 2020. DOI: 10.1016/j.labeco.2020.101835.

Sacerdote, B. (2001). Peer Effects with Random Assignment: Results for Dartmouth Roommates. The Quarterly Journal of Economics, 116(2), 681-704.

Sacerdote, B. (2011). Peer Effects in Education: How Might They Work, How Big Are They and How Much Do We Know Thus Far? In Erik Hanushek, Stephen Machin and Ludger Woessmann (ed.). Handbook of the Economics of Education, Elsevier, edition 1, volume 3, 249-277. ISSN 0169-7218, DOI: 10.1016/S01697218(11)03004-8.

Soetevent, A. (2006). Empirics of the identification of social interactions: An evaluation of the approaches and their results. Journal of Economic Surveys, 20(2):193 - 228.

Trogdon, J., Nonnemaker, J., and Pais, J. (2008). Peer effects in adolescent overweight. Journal Of Health Economics, 27(5), 1388-1399. http://dx.doi.org/10.1016/j.jhealeco.2008.05.003.

Yakusheva, O.,Kapinos, K. A., Eisenberg, D.(2014). Estimating Heterogeneous and Hierarchical Peer Effects on Body Weight Using Roommate Assignments as a Natural Experiment. Journal of Human Resources, Volume 49, Number 1, Winter 2014, pp. 234-261.

Zimmerman, David J. (2003). Peer effects in academic outcomes: Evidence from a natural experiment. Review of Economics and Statistics, 85, no. 1:9-23. 